NBER WORKING PAPER SERIES

\title{
JAMES TOBIN: AN APPRECIATION OF HIS CONTRIBUTION TO ECONOMICS
}

\author{
Willem H. Buiter \\ Working Paper 9753 \\ http://www.nber.org/papers/w9753
NATIONAL BUREAU OF ECONOMIC RESEARCH 1050 Massachusetts Avenue
Cambridge, MA 02138
June 2003

The views and opinions expressed are those of the author. They do not represent the views and opinions of the European Bank for Reconstruction and Development. Bill Brainard, Mike Wickens, Jan Magnus Casey B. Mulligan, Herschel Grossman, Robert Shiller and Mike Artis made valuable comments on earlier drafts. The views expressed herein are those of the authors and not necessarily those of the National Bureau of Economic Research.

(C2003 by Willem H. Buiter. All rights reserved. Short sections of text not to exceed two paragraphs, may be quoted without explicit permission provided that full credit including (C) notice, is given to the source. 
James Tobin: An Appreciation of his Contribution to Economics

Willem H. Buiter

NBER Working Paper No. 9753

June 2003

JEL No. B31, B41, C25, E21, E31, E32, E41, E44, E52, E62, E63, F32, F33, F41, G11, G20, I30

\section{$\underline{\text { ABSTRACT }}$}

Jim Tobin, who died on March 11, 2002 at the age of 84, was one of giants of economics of the second half of the twentieth century and the greatest macroeconomist of his generation. Tobin's influence on macroeconomic theory is so pervasive - so much part of our professional 'acquis' - that many younger economists often are not even aware that it is his ideas they are elaborating, testing, criticising, refuting or re-inventing. In this Appreciation, I consider Tobin's scholarly contributions, made over a period of more than 50 years.

Tobin received the 1981 Nobel Memorial Prize "for his analysis of financial markets and their relations to expenditure decisions, employment, production and prices". I consider his contributions to mean-variance portfolio demand and asset pricing theory, especially the Portfolio Separation Theorem; pitfalls in financial model building; portfolio balance and flow of funds models and the 'credit channel'; the life-cycle model and social security; econometric methodology, including the Tobit estimator and his pioneering work using both time series and cross-sectional data to estimate food demand functions; economic growth; Tobin's q; the 'Tobin Tax'; the monetary and fiscal policy effectiveness debate, first with Milton Friedman and then with the New Classical Macroeconomics and Real Business Cycle schools; and Tobin's approach to methodological questions including microfoundations and aggregation.

Willem H. Buiter

Office of the Chief Economist

European Bank for Reconstruction and Development

One Exchange Square

London, EC2A 2EH

United Kingdom

and NBER

buiterw@ebrd.com 
Jim Tobin, who died on March 11, 2002 at the age of 84, was one of giants of economics of the second half of the twentieth century and the greatest macroeconomist of his generation. ${ }^{1}$ Tobin's influence on macroeconomic theory is so pervasive - so much part of our professional 'acquis', that many younger economists often are not even aware that it is his ideas they are elaborating, testing, criticising, refuting or re-inventing.

Together with Markowitz, Tobin developed the mean-variance approach to portfolio choice under uncertainty. This became the demand-side - the interesting half - of the Capital Asset Pricing Model. Tobin was the father of empirical portfolio balance and flow-of-funds models. Together with William Brainard, he added greatly to our understanding of the transmission mechanism of monetary policy by giving us 'Tobin's $q$ '. His work during the 1960 s on explicitly including financial intermediaries in the monetary transmission mechanism contains fully worked-out models of what became known in the 1980s as the 'bank lending' or 'credit channel' of monetary policy. He made early and important contributions to the neoclassical theory of growth with outside money. He was a leading contributor to the theory and empirics of the life-cycle model of consumption, including the role of liquidity constraints. He pioneered the application of what is now referred to as the 'YaariBlanchard' version of the life-cycle overlapping generations model to the study of important monetary and fiscal policy issues using realistic numerically calibrated versions of that model. He made a seminal contribution to econometric methodology with the 'Tobit' estimator for a class of limited dependent variable models. In a decades-long debate with Milton Friedman, Tobin convinced most of the profession

\footnotetext{
${ }^{1}$ A somewhat unusual indicator of his achievement as a scholar is the fact that his name is associated both with a theory of the determinants of corporate investment, Tobin's $q$, and with a proposal for a tax on foreign exchange transactions, the Tobin tax, neither of which can, in my view, be counted among his three or four most important contributions to economic science.
} 
that the demand for money has an economically and statistically significant interest rate-responsiveness; that a constant growth rate for some monetary aggregate is unlikely to contribute to economic stability and that both monetary and fiscal feedback rules can, in principle, help stabilise the real economy. While he did not succeed in providing a fully 'Lucas-critique-proof' theory of a long-run non-vertical Phillips curve, he was a major contributor to the currently prevailing practical wisdom among central bankers and monetary economists, that monetary non-neutralities are persistent enough, predictable enough and stable enough to make (rules-bound) monetary stabilisation policy both feasible and desirable.

In this article, I will not attempt to convey a complete picture of this multifaceted, remarkable man, or even of the full range of the professional attributes I knew first hand - his qualities as a scholar, teacher, mentor, co-author, colleague, advisor of Presidents and other policy makers, passionate policy advocate, critic and friend. $^{2}$ For half a century, Tobin was Yale monetary and macroeconomics - some would say, Yale economics. His influence on his students, colleagues and co-authors was deep and pervasive. Tobin starts his Professional Autobiography with the sentence "Rare is the child, I suspect, who wants to grow up to be an economist, or a professor " (Tobin [1986b, p. 113]). Perhaps; but more rare even is the young student of economics taking his first tentative steps as a professional economist who, on becoming acquainted with Tobin, in person or through his writings, did not feel better about his choice of profession.

With one exception, the scope of what follows is restricted to Tobin's published scholarly contributions. The exception is an attempt to combine Tobin's

\footnotetext{
${ }^{2}$ Tobin wrote more than 500 papers, and it is impossible to provide a comprehensive overview in a single review article. Grossman [1975] is an interesting review of the first of Tobin's Essays in Economics (Tobin [1971]). Both Grossman [1982] and Lucas [1981b] contain critical reviews of Tobin [1980].
} 
published writings on social security reform with my distillation of some of Tobin's lecture notes on the subject - one that illustrates well both the intellectual rigour and the moral and political engagement of the man.

\section{Liquidity Preference, Separation and Asset Pricing}

Tobin received the 1981 Nobel Memorial Prize "for his analysis of financial markets and their relations to expenditure decisions, employment, production and prices”. With Harry Markowitz [1952, 1959, 1970] he developed what became the foundations of modern portfolio theory ${ }^{3}$. The key 'separation theorem' proven by Tobin [1958b], is that in a world with one safe asset and a large number of risky assets, portfolio choice by any risk-averse portfolio holder can be described as a choice between the safe asset and the same portfolio of risky assets. The ratio of the shares in the total portfolio accounted for by any pair of risky assets is the same for all risk-averse portfolio holders. The degree of risk aversion only determines the shares in the total portfolio accounted for by the safe asset and by the common portfolio of risky assets. This is an important and beautiful result, which is not done justice by Tobin's own summary: "Don't put all your eggs in one basket” (Tobin [1996b], p. 12). ${ }^{4}$ Indeed, Tobin's remarkable result is better summarised as 'regardless of your degree of risk aversion and caution, you will only need two baskets for all your eggs'.

For the mean-variance approach used by Tobin to be consistent with the von Neumann-Morgenstern expected utility approach to choice under uncertainty, either

\footnotetext{
3 'Modern' here means the Capital Asset Pricing Model (CAPM). I am not referring to Behavioural Finance theory developed by Kahneman and Tversky, Shiller, Shleifer, Thaler and many others (Kahneman and Tversky [1979], Shiller [1999, 2000], Shleifer [2000] and Barberis and Thaler [2002]).

${ }^{4}$ This phrase represented Tobin's own attempt, following the announcement of his Nobel award, at explaining his contribution to modern portfolio theory in words that might be understood by a befuddled journalist. It's a bit like summarising all of modern finance theory as.'How many ways can you say "there is no such thing as a free lunch",
} 
utility must be quadratic or the joint distribution of returns must be normal. Tobin was quite unapologetic about these restrictions on the domain of applicability of the approach, as is clear from this slightly irritated comment on Borch and Feldstein's [1969] critique on the Tobin [1958b] paper: "It is now more than a decade ago that I participated in the modest endeavour of doubling the number of parameters of investors' probability estimates involved in economists' analyses of asset choice. This extension from one moment to two was never advertised as the complete job or the final word,...” (Tobin [1969a]).

The theoretical work of Markowitz and Tobin in the 1950s on portfolio choice stimulated a large number of empirical studies of portfolio selection and asset market behaviour. The three Cowles Foundation Monographs edited by Tobin and Hester [1967a, b, and c] give one a good sense of the intellectual excitement of this period.

Tobin viewed his model of portfolio choice under uncertainty and the separation theorem as describing the behaviour of an individual portfolio manager, and he was not an unqualified admirer of the use made by Sharpe [1964], Lintner [1965] and Mossin [1966] of the mean-variance model. All three authors used the Tobin-Markowitz mean-variance model of portfolio selection as the 'demand side' of an equilibrium approach to the determination of asset prices. The separation theorem plus the assumption that all financial market participants share a common subjective joint distribution of rates of return means that the common portfolio of risky assets held by each and every portfolio holder has to be the market portfolio of risky assets. ${ }^{5}$

The resulting capital asset pricing model (CAPM) has since gone from strength to strength as theory and as a practical tool used by financial market analysts and fund managers. It is a remarkable example of a theory that emphatically fails

\footnotetext{
5 The "market portfolio" is a value - weighted index of all risky assets.
} 
empirically yet is generally considered to yield important insights. ${ }^{6}$ Among the key theoretical extensions have been the extension of the CAPM to multi-period portfolio selection (e.g. Mossin [1968] and Samuelson [1969]), the joint determination of consumption and portfolio selection over time using a CAPM framework (e.g. Merton [1969]) and the construction of dynamical general equilibrium models incorporating saving, capital formation and the CAPM approach to portfolio selection (e.g. Cox, Ingersoll and Ross [1985]).

The central reason for Tobin's reservations about the CAPM model was that the assumption of homogeneous beliefs effectively turned it into a representative agent model (Tobin [1983a]). Tobin viewed the representative agent assumption, popularised in macroeconomics since the 1970s by the New Classical school of Lucas, Prescott and Sargent, as a crucial oversimplification (see Lucas [1981, 1990], Kydland and Prescott [1982], Prescott [1986b], Stokey and Lucas with Prescott [1989] and Sargent [1987]). ${ }^{7}$ The massive transaction volumes observed day-by-day in the stock market, the government debt markets and most of all in the foreign exchange markets are driven mainly by traders taking or unwinding positions based on conflicting information and expectations. The CAPM model, with its homogeneous beliefs, has zero trade in equilibrium. This issue is considered at greater length in Section 9.

\footnotetext{
${ }^{6}$ The first implication of the CAPM is that all investors will choose to hold the "market portfolio". Since most investors hold very few assets in their portfolios, and different investors hold different risky portfolios, the CAPM model falls empirically at the first hurdle. Other in principle testable implications are that the market portfolio is mean-variance efficient and that risk premium on individual assets will be proportional to the risk premium of the market and the asset's beta coefficient - the ratio of the covariance between the return on the asset and the return on the market portfolio to the variance of return on the market. There is no fundamental difference between explanations of rates of return on risky assets based on market beta and those based on consumption beta theories (see Mankiw and Shapiro [1986]).

${ }^{7}$ I am not implying that these authors only use the representative agent model. All three authors have used non-optimising models and frequently use the overlapping generations model (e.g. Lucas [1972]).
} 


\section{Pitfalls in Financial Model Building: Portfolio Balance and Flow of Funds Models and the 'Credit Channel'.}

It is at first sight perhaps surprising that in his further theoretical and empirical work on portfolio theory in the 1960s, 70s and 80s, Tobin does not make extensive use of the mean-variance approach. ${ }^{8}$ Tobin's mistrust of the representative agent approach and his relaxed attitude towards micro foundations are consistent with his decision to pursue the empirical implementation of complete systems of portfolio balance and flow-of-funds models using asset demand specifications that were eclectic or ad-hoc as regards the selection of arguments.

Both in his solo-authored work (e.g. Tobin [1963a, b, 1969b, 1980, 1982a]) and in his co-authored work with Brainard (Tobin and Brainard [1963], Brainard and Tobin [1968]) and with Backus, Brainard and Smith (Backus, Brainard, Smith and Tobin [1980]), asset demand functions are not derived from optimising first principles. The arguments in the asset demand functions typically include current income, and financial wealth and the rates of return on all assets. A-priori constraints on the asset demand functions typically include 'homogeneity', that is, it is (anticipated) real rates of return, real income and real financial wealth that affect portfolio behaviour, and the 'adding-up constraint' on the entire system of asset demand functions. In the portfolio balance models or 'beginning-of-period' asset market equilibrium models favoured by Tobin in the $60 \mathrm{~s}$ and $70 \mathrm{~s}$, the adding-up constraint is the portfolio balance constraint or 'Walras' Law for stocks': instantaneous excess demands for asset stocks sum to zero - if there are $N$ assets, only $N-1$ asset demand functions can be specified independently. In the 'end-of-period' asset market equilibrium models favoured by

\footnotetext{
${ }^{8}$ In his empirical work with Brainard (Tobin and Brainard [1977]), there is a substantial section on risk in the CAPM spirit, and something analogous to 'beta' is used in the empirical work (Tobin and Brainard [1977, equation 3]. In this, as elsewhere, Tobin was more interested in the way the "fundamental" rather than "market" risks are priced). A later empirical paper with Brainard on the internationalisation of portfolios uses a mean-variance framework (Tobin and Brainard [1992]).
} 
Tobin after 1975, Walras' Law applies to the excess demand for all goods, services and financial assets the same way it does in traditional general equilibrium theory (Tobin [1980, 1982a], Tobin and Braga de Macedo [1980]), Tobin and Buiter [1980]).

The most natural interpretation of the rates of return that appear as arguments in these asset demand functions is that they are expected rates of return and that subjective conditional second and higher moments are suppressed. There is no presumption of financial market efficiency, whether in the sense of information arbitrage efficiency, fundamental valuation efficiency or Arrow-Debreu full insurance efficiency (see Section 8.1). Relative supplies of outside and inside financial assets can, in principle, influence equilibrium prices and returns.

The empirical implementation of complete systems of portfolio balance and flow-of-funds models has been a mixed success at best. Problems of collinearity among asset returns make the accurate estimation of own and cross effects problematic. Attempts to address this problem through the use of subjective priors were intriguing but in the end not wholly convincing.

Tobin's students and all those who read his work closely have benefited from the attention paid by Tobin to the key formal properties that any well-posed general equilibrium model (whether ad-hoc, behavioural, satisficing or optimising) must satisfy. Probably the most basic of these is the distinction between equilibrium conditions and budget constraints. The original motivation for the "Pitfalls" paper (Brainard and Tobin [1968]) and for Tobin's “General Equilibrium Approach to Monetary Theory" (Tobin [1969b]) had been the observation that empirically estimated asset demand functions often implied behaviour for the omitted asset demand function (omitted from estimation because of the portfolio balance constraint or Walras' Law) that was frankly incredible. It was neither the first nor the last time 
that distinguished economists would fail to verify or make proper use of the most basic properties of well-posed general equilibrium models: Walras' Law and the distinction between equilibrium conditions and budget constraints. ${ }^{9}$

The early papers by Tobin and Brainard on financial intermediaries, the transmission mechanism of monetary policy and the effectiveness of (quantitative) monetary controls (Tobin and Brainard [1963], Brainard [1964], Tobin [1969b, Section $8,1970 \mathrm{~d}]$ ) provided a pretty comprehensive characterisation of what became known more than two decades later as the 'bank lending' or 'credit channel' of monetary policy (Bernanke and Blinder [1988], [1992], Kashyap, Stein and Wilcox [1993]). However, unlike e.g Bernanke and Gertler [1989, 1995], these early contributions by Tobin and Brainard did not contain the rigorous and elegant asymmetric information and agency costs-based micro-foundations of the wedge between the cost of internal and external sources of funds to firms/entrepreneurs. ${ }^{10}$

\section{The Life-Cycle Model and Social Security}

Starting with his doctoral dissertation (Tobin [1947a]), household saving behaviour was central to Tobin's research and policy agenda. After Friedman [1957] and Modigliani (Modigliani and Brumberg [1954], Ando and Modigliani [1963]), Tobin comes a close third as regards the significance of his contributions to the lifecycle/permanent income approach. ${ }^{112}$ Tobin's dissatisfaction with the Keynesian

\footnotetext{
${ }^{9}$ It cannot be a coincidence that, as far as I have been able to determine, no student of Tobin's subscribes to the Fiscal Theory of the Price Level, a prominent recent example of the confusion of budget constraints and equilibrium conditions (Sims [1994], Woodford [1995], Cochrane [1998] and Buiter [2002]).

${ }^{10}$ As part of the graduate macroeconomics course at Yale, Tobin taught the Modigliani-Miller approach to the valuation of the firm, the limits to the applicability of M\&M insights and the reasons for the existence of differential costs associated with alternative sources of funds (internal, debt, equity) to enterprises. Bank loans were not included among the sources of finance in Tobin's ModiglianiMiller menu.

${ }^{11}$ Tobin considered Irving Fisher [1930], to be the originator of the life cycle model (Tobin [1967a]).
} 
consumption function was prompted in part by the failure of that theory to reconcile the cross-sectional and short-term time-series evidence (which showed the average propensity to consume declining with the level of income) with the long-run time series evidence which showed it to be constant. The hypothesis that rising financial wealth could reconcile the cross-sectional and short-run evidence with the long-run evidence, a hypothesis consistent with what later became known as the life cycle model, was stated and tested in Tobin [1951]. A number of further investigations of the empirical link between household consumption and the capital account followed (Tobin [1957] and Watts and Tobin [1960]).

The second reason Tobin abandoned the Keynesian consumption function was that it made little sense to an admirer of Irving Fisher [1930] to approach intertemporal choice with a static model. This consideration also led him to reject Duesenberry's Relative Income Hypothesis (Duesenberry [1949]) as a satisfactory approach to intertemporal consumption choice: the relative income hypothesis “...ignores the essential intertemporal nature of the consumption-saving choice. If high current consumption is the means to social status today, high future consumption is the means to social status tomorrow". (Tobin [1968d, 1975a p. 78]). ${ }^{13}$

During the sixties, seventies and eighties, Tobin made a number of key contributions to the theory and empirics of the life-cycle model, putting it in an AllaisSamuelson overlapping generations (OLG) setting (Allais [1947], Samuelson [1958]). Some of this work was joint with Walt Dolde (Tobin [1967a, 1972c], Tobin and Dolde [1971], Dolde and Tobin [1983]). Tobin's [1967a] paper is quite remarkable. For instance, it treats household births and deaths using the Yaari-Blanchard uncertain

${ }^{12}$ Tobin [1958c] is an interesting review of Friedman's book on permanent income (Friedman [1957]).

${ }^{13}$ A life cycle relative income (or relative consumption) hypothesis would not be subject to Tobin's objections to the original static relative income hypothesis. Even if its predictions for consumer behaviour need not be different from that implied by the conventional life-cycle model, its welfare implications would be radically different. 
lifetimes approach (Yaari [1965], Blanchard [1985], Buiter [1988]). The analysis is restricted to the consideration of balanced growth paths, but incorporates a wealth of relevant demographic and other characteristics. One key question it addresses is to what extent the life cycle model can, without a bequest motive, account for the kind of saving rates we see in the US. Tobin's answer was that it can account for most or all of it. The model was 'closed' with a neoclassical production function, which permitted the real interest rate to be endogenised. The empirical methodology employed is an early example of simulation using calibration. With only a modicum of hyperbole, one could describe Tobin as the methodological Godfather of the RBC school and methodology of Kydland and Prescott [1982]!

The papers with Dolde extend Tobin [1967a] in a number of dimensions. In Dolde and Tobin [1971], channels of potential monetary and fiscal influences on consumption behaviour are modelled, including liquidity constraints. These can take the form of a wedge between lending and borrowing rates or of quantitative constraints on the ability to borrow. The model does not allow for differences between nominal and real values, so the identification of some of the financial transmission channels as monetary policy effects is not secure. The analysis is again restricted to steady states. Both asset revaluations and liquidity constraints are shown to have potentially significant effects on aggregate consumption behaviour.

Dolde and Tobin [1983], uses a similar OLG model to analyse the macroeconomic effects of mandatory retirement saving. Many relevant features of the US tax system and social security retirement system are modelled and calibrated quantitatively. Again only steady states are considered. These numerical, calibrated OLG models can be seen as precursors of the full-fledged 55-period overlapping generations models constructed and calibrated numerically by Auerbach and Kotlikoff 
[1987]. Auerbach and Kotlikoff took the further major step of analysing the behaviour of an aggregate growth model with an OLG household consumption specification from arbitrary initial conditions, thus permitting the consideration of non-steady state behaviour. Their 'generational accounts' approach to summarising the direct effects of the budget on intergenerational distribution provides a natural and coherent framework for studying the intergenerational fairness issues that were a central concern of Tobin.

Tobin's view that economics is a toolkit that can and should be used to address practical problems is reflected also in his exploration of the implications of the lifecycle/permanent income approach for the saving and portfolio allocation decisions of foundations and similar institutions (e.g. private universities) that manage an endowment for the benefit of current and future cohorts of students (Tobin [1974c]).

As a further illustration of the power of the combination of Tobin-Markowitz portfolio analysis and the life-cycle model, between 1971 and 1978, Yale University offered the Tuition Postponement Option, or TPO, as an alternative to student loans. Tobin was the architect of this important and innovative scheme, which, because of its group repayment feature, offered a form of (labour) income insurance not available elsewhere. ${ }^{14}$ After graduation, students who elected the plan were committed to pay off their loans by paying Yale 0.4 percent of their annual income for every $\$ 1,000$ borrowed. The scheme was intended to have higher income graduates supporting (subsidising) their low income classmates. To achieve this, classes pooled their collective debts and paid in cohorts. Under the original scheme, TPO participants were required to keep paying until the entire cohort had paid off its debt.

\footnotetext{
${ }^{14}$ It is similar in spirit to the venerable 'Tantièmes', a group annuity with the feature that a given annuity benefit is shared by the surviving members of the pool. Here the short-lived end up subsidising the long-lived. Unlike the TPO complainers, those who end up paying the Tantièmes subsidy do not complain.
} 
Alternatively, they could buy out their individual loans at 150 percent of the loan plus interest. Subsequently, Yale agreed to cancel a cohort's debt if that cohort still owed after 35 years.

Unsurprisingly, complaints about the program started when a number of high-earning graduates during the eighties and nineties realized that their accumulated repayments far exceeded in real terms (and in present discounted value) the amount borrowed. A further complaint was that, until Yale capped the repayment period at 35 years, there seemed to be no end to the repayment period. The highest-earning graduates ended up subsidizing both those 'performing' classmates who earned less than them and those classmates who chose to default on their loans. The subsidisation of the honest poor by the honest rich was a key design feature of the scheme. Only to the extent that the realised default rate (about 15 percent) was higher than anticipated, did the high earning graduates have just cause for complaint. It is probably true that Tobin and those who implemented the scheme had underestimated the magnitude of the adverse selection problem the scheme would face.

The labour income insurance feature of Tobin's TPO scheme is an example of the kind of security and well-being enhancements of "ordinary riches" that can be designed by applying the insights of Tobin-Markowitz portfolio analysis and the lifecycle model. Robert Shiller [2003] has recently extended and expanded these ideas in a number of innovative ways.

Tobin frequently addressed the efficiency and equity issues associated with alternative mechanism for providing for income during retirement (see e.g. Tobin [1967a, 1976, 1988, 1990a], Tobin and Dolde [1971], Dolde and Tobin [1983], Friedman [1976]). Like all his students, I learned to appreciate the versatility and power of the OLG model, which was used intensively in his graduate lectures. Even 
the simplest 2-period version provides a natural analytical framework for studying retirement saving and social security issues. Because it allows for at least one key demographic form of heterogeneity among consumers, it also represents a natural analytical vehicle for combining a Keynesian approach to the macroeconomic consequences of deficit financing and alternative social security systems - which requires heterogeneous consumers - with the explicit intertemporal optimising approach Tobin so admired in Irvin Fisher [1930].

Tobin taught me social security issues using the Diamond [1965] model. This superimposes on the one-sector neoclassical growth model the saving behaviour of the two-period OLG model. There is an infinite sequence of generations each of which lives for two periods, supplies a fixed amount of labour and pays social security contributions when young and lives off retirement savings and social security retirement benefits when old. Starting from a situation without government, with only private savings as a source of retirement income, an unfunded or pay-as-you-go, social security retirement scheme is introduced in period $t$. This taxes the young (workers) each period and pays all the receipts of this social security tax out to the old (retirees) in that period. ${ }^{15}$ For simplicity, assume that each generation pays a constant share of its wage income when young in social security taxes - a defined contribution scheme. ${ }^{16}$ Compared to what would have occurred in the absence of the unfunded

\footnotetext{
${ }^{15}$ These unfunded, pay-as-you-go social security retirement schemes, Tobin referred to as the 'taxtransfer view' of social security. Mandatory retirement saving, with individual accounts entitling to holder to the market rate of return, and converted on retirement into annuities with a market-determined return would be the pure version of what Tobin referred to as the 'insurance view' of social security.

${ }^{16}$ Let $N_{t}$ be the number of young workers in period $t$, (also the number of old retirees in period $t+1$ ).

Let $\tau_{t}$ be the per capita contribution of the young workers in period $t$ and $b_{t}$ the per capita retirement benefit paid out in period $t$ to the old in period $t$. An unfunded scheme is, by definition, a balancedbudget scheme: $N_{t} \tau_{t}=N_{t-1} b_{t}$. Clearly, with $N_{t}$ and $N_{t-1}$ given, the contribution rate and the benefit rate cannot be specified independently. The defined contribution (that is, exogenous contribution) version of the unfunded social security retirement scheme fixes the contribution rate $\tau_{t}$ and treats the benefit rate $b_{t}$ as endogenously or residually determined. The defined benefit (that is,
} 
social security retirement scheme, its introduction will reduce the total stock of private financial wealth in the economy (the saving of the young). In a closed economy, it will also reduce the capital stock. It will reduce the flow of private saving (the sum of saving by the young and dissaving by the old) if there is positive population growth or if there is positive labour productivity growth. ${ }^{17}$

Introducing a pay-as-you-go, unfunded social security retirement scheme (an intergenerational redistribution scheme) in period $t$ provides a windfall to the generation that is old in generation $t$. This generation made no social security retirement contributions when young, but nevertheless gets retirement benefits when old. My grandparents were in that position, and they were both pleased and amazed at this windfall. Generations born in period $t$ or later, that will both pay the tax when young and receive the benefit when old, will be worse off (better off) with the social security retirement scheme than without it if the 'biological rate of return' on the unfunded social security retirement scheme, the sum of the population growth rate and the growth rate of labour productivity, is below (above) the market rate of return on saving

With declining birth rates, increasing life expectancy and, in the industrial countries outside the US, disappointing productivity growth, there are strong pressures to reduce the scope of unfunded social security retirement schemes or even to abolish them, and to replace them by a mixture of mandatory and voluntary fully funded retirement saving schemes. While Tobin was not opposed to a greater role for

exogenous benefit) version of the unfunded social security retirement scheme fixes $b_{t}$, the retirement benefits of the old and makes $\tau_{t}$, the social security tax on the young endogenous.

${ }^{17}$ Let $S_{t}$ be aggregate private saving in period $t, S_{t}^{y}$ per capita saving by the generation that is young in period $t, N_{t}$ the size of generation $t$ and $n_{t}$ the growth rate of population between periods $t$ and $t-1$. Then $S_{t}=N_{t}\left(s_{t}^{y}-s_{t-1}^{y}\right)+n_{t} N_{t-1} s_{t-1}^{y}$. The statement in the text requires $s_{t-1}^{y}>0$ and $s_{t}^{y}>s_{t-1}^{y}$ if (labour-augmenting) productivity growth is positive. 
funded social security retirement financing, he considered many of the arguments advanced in support of increased funding to be flawed and some dishonest.

First, as a point of logic, it can make no sense to speak of the deficit of or the future liability implied by, a pure unfunded social security retirement scheme. Such schemes pay out each period what they get in - no more, no less. They are balancedbudget schemes by definition. It is true that most real-world social security retirement schemes specify the contribution rates of the young and the benefit entitlements of the old quite independently of each other, without respecting the requirement that they should balance period-by-period. Clearly, if balance must be preserved, either periodby-period, as in the pure unfunded scheme or, in present value terms, over longer periods, and if contributors in period $t$ base their expectations of the 'replacement ratio' (benefits in period $t+1$ relative to wages in period $t$ ) on the benefits received by their parents in period $t$ (relative to wages in period $t-1$ ) or on their own contribution rates (social security taxes in period $t$ relative to wages in period $t$ ), there are bound to be surprises. When birth rates are falling, life expectancies are rising and/or productivity growth is disappointing, the expectations of retirees concerning their retirement income can only be fulfilled with rising social security contribution rates for workers, or constant contribution rates for workers will imply that retirees will have lower replacement rates and lower retirement incomes than they expected while young: the surprises will be disappointments - the reverse of what occurred with the introduction of unfunded social security retirement schemes in the 1930s.

Tobin always emphasized that unfunded social security is about intergenerational distribution. When there have been unfavourable demographic or productivity surprises, restoring balance, whether immediately or over a longer time horizon, implies intergenerational conflict (Tobin [1990a]). Unless social security 
reform reduces or eliminates other distortions, the reduction in the unfunded component and increase in the funded component inevitably mean that some generation (or generations) will be worse off, having made contributions while young but not getting the benefits they expected while old. Therefore, the downsizing or abolition of an unfunded social security retirements scheme does not represent a Pareto-improvement, even if the (risk-adjusted) rate of return on private saving (and on the funded mandatory retirement saving schemes) exceeds the biological rate of return in every period.

Proponents of a reduction in the scale and scope of unfunded social security retirement schemes stress the positive effect on aggregate financial wealth (and on private saving) of a reduction in the scope and scale of unfunded social security. ${ }^{18}$ This only makes sense if stock of financial wealth and (in a closed economy) the capital stock is too low, that is, if the saving rate of the young is too low. However, the only violation of dynamic efficiency that can occur in the pure Allais-SamuelsonDiamond OLG model with lump sum social security contributions and benefits is too large a stock of financial wealth of capital. Saving by the young could be so high that it drives the rate of return on capital below the natural rate of growth for ever. The pure unfunded social security retirement scheme effects lump-sum intergenerational distribution from the young to the old (which unambiguously reduces saving by the young). It will therefore never aggravate and may alleviate dynamic inefficiency. The reduction in saving by the young that it causes is not inefficient.

\footnotetext{
${ }^{18}$ Note that, according to footnote 14 , the sign of the effect of such reforms on the stock of private financial wealth is unambiguously positive, but the effect on the flow of private saving, while likely to be positive, could be negative if the growth rate of population is negative or if productivity growth is negative.
} 
Unfunded, pay-as-you-go social security retirement is also about intergenerational risk sharing or insurance. ${ }^{19}$ Through these balanced budget intergenerational transfers, forms of intergenerational risk-sharing are possible that cannot, in general, be reproduced through private sector risk-sharing facilities. Funded schemes permit, if the retirement savings are invested wisely, the diversification of financial asset risk. They do not permit the diversification of wage income risk across generations.

This is of course not the end of the story. It is not difficult to think of generalisations of the simple OLG model used here that could indeed cause saving to be 'too low'. Endogenous labour supply, including an endogenous age of retirement, mean that the social security tax is not lump-sum. Further distortions are introduced by other aspects of the tax - transfer system, such as the taxation (sometimes double taxation) of the returns to saving. Still, from the point of view of efficiency as well as of social and generational welfare and justice, the point made by Tobin that the case for reducing the scope of pay-as-you - go unfunded social security retirement schemes and for moving to a greater role for funding social security retirement through a mixture of mandatory and voluntary retirement saving schemes, is not straightforward or obvious (see e.g. Geanakoplos, Mitchell and Zeldes [1998, 2002] for an update on this debate in the US).

\section{Econometric Methodology}

During the 1950s, Tobin made two important contributions to econometric methodology. The first of these was his exploration of the combined use of aggregate

\footnotetext{
${ }^{19} \mathrm{I}$ am using intergenerational insurance here in a sense that is quite different from what Tobin referred to as the 'insurance view' of social security, which refers to fully funded, mandatory retirement saving (possibly with individual accounts).
} 
time series data and cross-sectional family budget survey data to study the demand for food (Tobin [1950]). ${ }^{20}$ Almost 50 years later, during 1995, 1996 and 1997, this study was used in an econometric methodology experiment organised by Magnus and Morgan [1999]. Eight teams of contemporary econometricians participated in a "field trial experiment" in which each team applied its preferred statistical and econometric methods to (up to) three sets of data (Tobin's original data set, further US data (after 1950), and similar Dutch data). The common task for all teams was to estimate the income elasticity of food demand, to test the homogeneity postulate of the family food demand function and to comment on the differences between their results and Tobin's. Those who know both the original paper and the eight field trial follow-ups will concur with Tobin, who attended the Workshop following the experiment, that the 1950 Tobin “...wrote a pretty good paper” (Tobin [1997, p. 647]).

The second is a seminal contribution to the estimation and testing of multiple regression models with limited dependent variables (Tobin [1958a]). ${ }^{21}$ A few years earlier, Tobin had written an early application to economic data of the binomial probit model (Tobin [1955a]). This estimator originated in biology, where it is used to estimate how the observed probabilities of positive or negative responses to treatment vary with observable characteristics of the organism and the treatment. Tobin's empirical application to automobile purchases brings out one of the limitations of the probit model. Treating car purchases as a binary variable - assigned a value of 1 if you buy a car, 0 if you don't - throws away a lot of information. The distribution of spending on cars is censored or truncated from below at 0 , but above zero is more

\footnotetext{
${ }^{20}$ In a joint paper with Houthakker, Tobin used time series and cross-sectional data to estimate demand functions for rationed foodstuffs using pre-World War II UK time series data (1920-1938) and two prewar household expenditure surveys (Houthakker and Tobin [1952]). Rationing in the UK lasted until 1954. Tobin was on leave at Cambridge during 1949-50, and experienced rationing first-hand. Characteristically, this real-world encounter gave rise to a number of theoretical and empirical papers on rationing (Tobin [1952b], Tobin and Houthakker [1951] and Houthakker and Tobin [1952]).

${ }^{21}$ Also called the econometric theory of qualitative response models.
} 
appropriately treated as continuous. ${ }^{22}$ When the dependent variable is censored a key assumption of OLS regression is violated: the regression errors are correlated with the regressors, and OLS estimates will be biased and inconsistent. Tobin developed what became known as the Tobit estimator, a hybrid of probit analysis and 'ordinary' multiple regression. ${ }^{23}$ The field of qualitative response models, limited dependent variables, censored data and selection bias has grown explosively and has recently produced a couple of Nobel Memorial Prize winners if its own. ${ }^{24}$

\section{Economic Growth}

Tobin made a number of key contributions to the theory of economic growth. His "Dynamic Aggregative Model" (Tobin [1955b]) does not receive the credit it deserves as a precursor of the one-sector neoclassical growth model developed in full by Swan [1956] and Solow [1956]. ${ }^{25}$ Not only does Tobin's model have the key features of the one-sector neoclassical growth model (a neoclassical two factor production function in capital and labour, smooth capital-labour substitution, competitive factor markets), it includes quite a few other features and variants (outside fiat money alongside capital in the asset menu, rigid money wages and business cycle fluctuations). It is probably the vast ambition of the paper and its

\footnotetext{
${ }^{22}$ Strictly speaking, if households can sell as well buy cars, the non-negativity constraint applies only to the stock of cars held, not to sales or purchases in any given period. Even the non-negativity constraint on the stock of cars applies only to physical quantities, not to ownership claims to cars, if there were a market for short selling such claims.

23 The story of the origin of the name for the Tobit estimator is too good not to repeat here. During World War II, Tobin served in the US Navy. He makes a brief appearance in Herman Wouk's novel The Caine Mutiny (Wouk [1951]). One of the main characters, Willie Keith, has ambitions to be first in his class when entering midshipmen school, but soon sees that this will be denied him: "A mandarinlike midshipman named Tobit, with a domed forehead, measured quiet speech, and a mind like a sponge, was ahead of the field by a spacious percentage".

${ }^{24}$ James Heckman and Daniel McFadden won the Nobel Memorial Prize for Economics in 2000. Heckman's Heckit estimator echos Tobit (Heckman [1979]).

${ }^{25}$ Joan Robinson [1956] is another economist whose contribution to modern growth theory has been undervalued.
} 
failure to deliver on every ambition that account for the too limited recognition it has received.

In two further important papers, Tobin [1965a, 1968b] develops a rigorous positive and normative approach to economic growth in a monetary economy under full employment. He revisited the issue two decades later in Tobin [1986a]. Money is an outside fiat asset, supplied only by the government and with its nominal rate of return fixed (say at zero). The benchmark model (most clearly analysed in Tobin [1968b]) has money and capital as perfect substitutes: their pecuniary rates of return must be equal in any equilibrium where both are held. A higher growth rate of the nominal money stock increases the steady state rate of inflation one-for-one. With the nominal interest rate on money fixed, this reduces the real rate of return on money one-for-one. Asset market equilibrium requires the rate of return on capital to fall pari passu. The aggregate capital-labour ratio therefore has to rise. Thus higher monetary growth and higher inflation are 'good for capital formation'.

The same result can be obtained in the deterministic one-sector neoclassical growth model with OLG consumption and portfolio choice (e.g. the Diamond [1965] model) with outside fiat money added as a store of value alongside real capital. If outside fiat money (again with an exogenous nominal interest rate) is only held as a store of value, its rate of return will have to equal the rate of return on capital in equilibria where both money and capital are held.

These models are vulnerable to the introduction (by the public or the private sector) of nominal assets with endogenous positive nominal interest rates (nominal bonds), since such claims would dominate money as a store of value. More fundamentally, since 'money' is neither a means of payment nor a medium of 
exchange in these models, the use of the word 'money' does a disservice to linguistic clarity. I prefer to refer to the asset in question as 'pet rocks' or 'candy wrappers' ${ }^{26}$

Sidrauski's [1967] monetary growth model made real outside fiat money balances an argument in the direct utility function. With the long-run rate of return on capital tied down by the exogenous rate of time preference of the representative consumer/portfolio holder, different rates of nominal money growth and different steady state rates of inflation are not reflected in different steady-state capital labour ratios or consumption per capita (they are associated with different steady state ratios of money to capital and different steady state utility levels). The traverse between steady states will, however, in general depend on the monetary rule (see Fisher [1979]).

Together with Solow, von Weizsäcker and Yaari, Tobin made an interesting contribution to the neoclassical growth model with fixed factor proportions (Solow et. al. [1966]). The vintage capital approach to modelling augmentable inputs remained a favourite of Tobin's.

Tobin was a 'green' economist long before this became fashionable. In "Economic Growth as an Objective of Government Policy" (Tobin [1964]), Tobin questions and qualifies the arguments for 'growthmanship' (the advocacy of paths that promise more consumption later in return for less earlier), evaluates the non-economic arguments for growth, addresses the "Growth in What" question (total consumption vs. per capita consumption; the treatment of leisure), the power of government to influence growth and how different market failures drive a wedge between the private and social rates of return to saving.

\footnotetext{
26 'Pet rocks' does not capture the divisibility of money very well, but it does signal the other key properties of the asset in question. It is not valuable as a consumption good, capital good or intermediate input; it is not used as a means of payment or medium of exchange; its supply and its nominal rate of return are exogenous.
} 
The study by Nordhaus and Tobin [1973a, b], "Is Growth Obsolete", is a textbook example of how good economics can be used to articulate and quantify 'green' concerns. The paper addresses three key questions. The first, "How good are the measures of output currently used to evaluate the growth of economic welfare?" is answered by Nordhaus and Tobin constructing their own preferred Measure of Economic Welfare (MEW). Starting from GNP, they first reclassify GNP final expenditures among consumption, investment and intermediate. They impute for the services of the stock of consumer capital, for leisure and for the product of household work and correct for some of the disamenities of urbanisation. They found that their MEW for the American economy did grow over the period under study but more slowly than GNP.

The second key question, "Does the growth process inevitably waste our natural resources?" gets a tentative negative answer, although the authors point to many failures of the price mechanism to price externalities properly. The authors also make no attempt to address the likelihood and severity of global ecological catastrophes. In response to the third question "How does the rate of population growth affect economic welfare?" the authors point out that population growth cannot continue forever and take comfort from the slowdown already apparent at the time of writing in the US. One may or may not concur with the authors' overall conclusion, that good, well-managed growth is not obsolete. There can be no doubt about the value of their hard-nosed economic analysis of what had until then been rather soft issues. The combination of soft hearts and hard heads is definitely to be preferred to its opposite.

\section{Tobin's $q$ and the Transmission of Monetary Policy}


"Tobin's q" (which might, in fairness, be called "Tobin and Brainard's q") is the ratio of the market valuations of capital assets to their replacement costs, say the price of existing houses relative to the cost of building comparable new ones. ${ }^{27}$ For corporate businesses, the market valuations are made in the securities markets, the markets for corporate equity and debt. Brainard and Tobin [1968] proposed $q$ as a superior summary measure or indicator to 'the' rate of interest of the role played by financial factors in the capital investment decisions of enterprises and households. ${ }^{28}$ Investment would be higher, ceteris paribus, the higher the value of $q$. Household financial wealth, of which the market value of the corporate sector is an important component, would move with $q$ and drive private consumption. Tobin viewed this as a more likely and more reliable transmission mechanism for monetary policy than nominal and real interest rates. ${ }^{29}$ The idea of a central role for $q$, which has its (acknowledged) origins in Keynes's General Theory (Keynes [1936]) was further elaborated in Tobin and Brainard [1977]). A rather amusing response to a PostKeynesian critique of $q$-theory (Crotty [1990]) can be found in Tobin and Brainard [1990].

It was soon pointed out, by Hayashi [1982] and others, that Tobin's $q$ could be interpreted as the shadow price of installed capital in an optimising neoclassical model of investment subject to internal and strictly convex (e.g. quadratic) costs of capital stock adjustment. If both the production function and the adjustment cost function are linear homogeneous in their arguments, the shadow price of installed

\footnotetext{
${ }^{27}$ The concept now known as Tobin's $q$ was first introduced (and discussed at length) in Brainard and Tobin [1968]. In Tobin and Brainard [1990], footnote 1 states, referring to " $q$-theory" "The idea was first published in an earlier Brainard and Tobin paper (1968)".

${ }^{28}$ To the question "why did you name it ' $q$ '?" Tobin's answer was, "Because ' $p$ ' was already taken."

${ }^{29}$ The evidence on the magnitude of the intertemporal substitution elasticity of private consumption is by no means strongly supportive of a positive real interest rate effect on private saving (see e.g. Hall [1988], Epstein and Zin [1991],
} 
capital (Tobin's marginal $q$ ) is equal to the average value of the installed capital stock (Tobin's average $q$, that is, Tobin's $q$ ).

Tobin believed that the relevance of $q$ theory was not dependent on the applicability of the neoclassical interpretation. The neoclassical interpretation is interesting, however, because it highlights a number of conditions under which Tobin's $q$ will fail to reflect accurately the incentives for investment. Consider for instance a putty-clay type technology where the energy intensity of production is variable ex-ante, but fixed ex-post. Assume that past investment was undertaken on the confident assumption that the price of energy would be low. An unexpected increase in the price of energy would reduce the value of existing capital vintages, which embody energy-intensive technology, that is, Tobin's (average) $q$ would fall. Nevertheless, the incentive to invest in new capital equipment embodying less energyintensive technologies could be high (Tobin's marginal $q$ could be high relative to Tobin's average $q){ }^{30}$

Empirical tests of $q$ theory are subject to an endogeneity problem that goes beyond the simultaneity and endogeneity problems encountered when estimating, say, a market supply function by regressing quantity on price. If the market is competitive, the price of the an individual firm's output can be taken as parametric, or exogenous to that firm. ${ }^{31}$ A supply curve can be viewed as an aggregation of decision rules of individual firms, with each individual decision rule expressing the firm's instrument (quantity produced) as a function of something exogenous to the firm (market price). In the neoclassical interpretation of $q$ as the shadow price of installed capital, $q$ cannot

\footnotetext{
${ }^{30}$ The discussion of the distinction between marginal and average $q$ in Tobin and Brainard [1977] uses the example of an increase in energy costs when technology is represented by a heterogeneous (vintage) capital model of the kind proposed in Solow, Tobin, von Weizsäcker and Yaari [1966].

${ }^{31}$ Even if the market price is parametric to the individual competitive firm, there could be a non-zero correlation between the market price and the residual in a regression of quantity supplied on market price using individual firm-level data.
} 
be taken as parametric or exogenous even for an individual competitive enterprise. A regression of investment on $q$ using individual firm data does not recover a decision rule expressing a choice variable of the firm to something parametric or exogenous to the firm. In the neoclassical interpretation, the value of $q$, the current value co-state variable associated with the capital stock state variable, is determined jointly with the firm's investment decision - together they characterise the firm's optimal investment programme. Even if one does not adopt the neoclassical interpretation of Tobin's $q$, the market value of the firm will reflect the market's assessment of the past, current and anticipated future decisions of the firm. It therefore cannot therefore be taken as parametric to the firm.

There are other pitfalls in empirical tests of $q$ theory. The market value of a firm represents not only the value of its reproducible assets, but also the value of its irreproducible assets, such as land. There is no problem of principle, since the reproduction cost of a piece of land is infinite, so Tobin's $q$ for land would be zero, as it should be. In practice, however, one seldom has the detailed information required to strip out the irreproducible assets from the firm's balance sheet. Also, much or even most of the market value of an enterprise may be due to intangibles, such as 'goodwill', including the value of the enterprise as a going concern. It is clear that the market value of Microsoft bears little relationship to the market value of its reproducible tangible assets. Conventional tests of Tobin's $q$, that involve a regression of fixed investment on the market value of the firm deflated by some broad price index of investment goods, are unlikely to work well for firms like Microsoft. 
Despite all these problems and shortcomings, $q$ theory is unlikely to go away, as it is consistent with a wide range of approaches to the determinants of business investment and can be empirically implemented using generally available data. ${ }^{32}$

\section{The 'Tobin Tax'}

Like Keynes, Tobin was sceptical about the long-run rationality of securities markets. Keynes concluded that the liquidity of these markets is a mixed blessing and advocated a substantial transfer tax on transactions in securities “... with a view of mitigating the predominance of speculation over enterprise in the United States" (Keynes [1936, Ch. 12]). For similar reasons, Tobin advocated on at least two occasions, an international transfer tax on transactions across currencies (Tobin [1974a, pp. 88-92, 1978]).

Tobin's proposal "to throw some sand in the wheels of our excessively efficient international money markets" (Tobin [1978, p. 154]) aimed to restore the ability of central banks and governments to pursue monetary and fiscal policies appropriate to their internal economic circumstances. It hoped to achieve this by restricting international financial capital mobility and thus to uncouple national interest rates to a greater extent.

Tobin's first choice (unconstrained by political realities) would have been a global common currency, common monetary and fiscal policy, and economic integration (Tobin [1978, p. 154-155]). Failing that, a floating exchange rate with a transaction tax on foreign exchange market transactions was the least bad solution.

Tobin's position on what the first-best choice would be is clearly an internationalist, multilateralist one. I share his view that, under unrestricted

\footnotetext{
${ }^{32}$ For an early influential empirical implementation to US business fixed investment see Summers [1981].
} 
international financial capital mobility, a floating exchange rate buys at most a severely restricted degree of national monetary and fiscal policy independence. However, it is hard to see how a Tobin tax, even if it could be administered effectively, would do much to restore or enhance the domain of domestic monetary policy autonomy. Nor is it obvious that it would materially reduce excessive exchange rate volatility and/or limit the duration and magnitude of exchange rate misalignments. For the tax to have a marked effect in any of these dimensions, it would have to be quite punitive and would put at risk not just easily reversed will-o'the wisp foreign exchange transactions, but also socially productive international financial intermediation.

Tobin [1978] also contains the suggestion that the tax proceeds could be paid into the IMF or the World Bank, although this was not an integral part of his proposal. This suggests a quite different rationale for a transactions tax in the foreign exchange markets: even a low tax rate could be an important source of revenues for funding economic development on a concessional basis. As a rule, earmarking or hypothecating specific taxes for specific expenditures if there is no user-charge-type link between the two, leads to inefficient overall budgeting and should be discouraged. Given the dearth of grants and other concessional finance available for economic development, it may be possible to defend such a dedicated tax on $N^{\text {th }}$ best grounds.

The global anti-globalisation movement thought for one brief moment that they had found an ally in the author of the Tobin tax. They were soon to be disappointed. Tobin was sceptical of the benefits of international financial integration in a world with multiple currencies, but he was a strong supporter of free trade and multilateralism. He favoured government assistance to the losers in the trade liberalisation process, but with the support designed to assist the reallocation of 
resources from dead-end industries towards viable new uses, rather than to subsidize the continued use of resources in non-viable industries. Tobin forcefully repudiated the anti-globalisation mantra of the Seattle crowd and distanced himself quite emphatically from the enemies of trade liberalisation, globalisation and the open society.

\section{Monetary and Fiscal Policy Effectiveness}

The role of monetary and fiscal stabilisation policy, that is, the scope for the monetary and fiscal instruments to be used effectively to dampen excessive fluctuations, set a floor under real economic activity and a ceiling on inflation, was an abiding interest of Tobin. He addressed each of the key issues that must be settled before the active use of monetary and fiscal policy for stabilisation purposes can be recommended.

First, a case must be made that the normal operation of an 'unaided' modern market economy is likely to lead to inefficient, socially costly outcomes. It is not straightforward to come up with a definition of an 'unaided' modern market economy that would represent an acceptable benchmark with which to contrast an activist policy. What constitutes a passive, 'hands off' monetary and budgetary policy stance? Are the Taylor Rule and the McCallum rule passive or activist (Taylor [1993, 1999], McCallum [1988, 1999])? Do the automatic fiscal stabilisers represent active or passive fiscal policy? To focus the argument, I define activist stabilisation policy to include all contingent rules, that is, all policy behaviour that incorporates feedback to the instruments from information about past, present or anticipated future behaviour of exogenous, state or endogenous variables. This includes all feedback rules, like the Taylor and McCallum rules and the use of the automatic fiscal 
stabilisers. It includes both rules with credible commitment and opportunistic behaviour. For concreteness the no-feedback, passive benchmark policy for monetary policy can be thought of as either a constant nominal growth rate for some monetary aggregate, or a constant short nominal interest rate or a fixed nominal exchange rate. Passive fiscal stabilisation policy can be thought of as a balanced budget rule. ${ }^{33}$

Second, it must be shown that competent, well-informed and well-intentioned policy makers, capable of credible commitment, could improve on the passive rules, that is, that there is in principle scope for welfare-enhancing monetary and fiscal stabilisation policy.

Third, the case must be made that the actual institutions and policy makers we have (or have some hope of creating, electing or appointing) can be trusted, if given the means, to design and implement rules and to pursue policies that would enhance economic well-being.

\subsection{Market Failure}

As regards the identification of important and persistent forms of market failure, Tobin believed that there were essential departures from the efficient competitive market clearing paradigm in the labour markets and in the financial markets. From his very first published paper (Tobin [1941]) to some of the last he wrote (Tobin [1995]), Tobin addressed the issue of the failure of labour markets to clear. He always retained the view that Phillips curves (strictly speaking the Phillips curve should be called the Fisher [1926] curve) were non-vertical in the run relevant for the design and implementation of stabilisation policy (see e.g. Tobin [1967b,

\footnotetext{
${ }^{33}$ Balancing the budget continuously requires some contingent response of spending and/or tax rates to shocks to and fluctuations in tax bases. It is arguable whether this is active or passive policy. Tobin repeatedly stated his fundamental disagreement with balanced-budget policies or constitutional amendments (Tobin [1981, 1982b]).
} 
1968a, 1972a and 1973a]). He was not doctrinaire about whether the exploitable nonvertical short-run Phillips curve was due to incomplete one-or-more period(s) ahead nominal wage or price contracts that (partly) pre-determine the current money wage or general price level, or to systematic and persistent forecast errors by suppliers of labour or other price setters. His initial response to the search-theoretic underpinnings of the Phillips curve initiated in Phelps et. al. [1970] and in Phelps [1972], was not very positive, partly because they were a little too invisible handish for his taste (all unemployment is frictional) and partly because the early search models had too many counterfactual implications for the behaviour of job separations over the cycle and other observables. Subsequent developments in this literature involving two-sided asymmetric information in the labour market have remedied some of these weaknesses. They imply that the invisible hand does not necessarily support Paretoefficient equilibria and avoid obviously counterfactual empirical predictions (see e.g. Pissarides [2000]).

In his Presidential Address to the American Economic Association Tobin [1972a] sketches a theory of stochastic macroequilibrium that preserves an aggregate unemployment-inflation trade-off in the long run: “..random intersectoral shocks keep individual labour markets in diverse states of disequilibrium...” but “..the perpetual flux of particular markets produces fairly definite aggregate outcomes..." of unemployment and wage inflation. The key non-homogeneity that supports a non vertical range (at high unemployment rates) for this long-run Phillips curve is that there is a temporary floor on the rate of decline of nominal wages in excess supply markets, independent of the amount of excess supply, of the past history of wages and prices and of anticipated future price and wage behaviour. This floor will be present in any particular market until a sufficiently high level of unemployment has persisted 
in that market for several periods. As long as there are individual markets where this floor is a binding constraint, there can be determinate rates of economy-wide wage inflation for various levels of aggregate demand (and aggregate unemployment). The floor phenomenon can, within limits, preserve a Phillips curve trade-off. As aggregate demand rises and aggregate unemployment falls, fewer and fewer individual markets will be at the floor. For low enough levels of aggregate unemployment, the Phillips curve becomes vertical. A detailed formal development of the model sketched in Tobin's Presidential Address can be found in Iwai [1981].

Tobin characterises the assumption that there is a floor on nominal wage changes as "A rather minor modification" to a model in which "actual wage increases eventually feed fully into the equilibrium components of future wage increases". ${ }^{34}$ I cannot agree with that characterisation, as the floor represents a key non-homogeneity, that is, a form of money illusion or inflation illusion, albeit a temporary one. It might be possible to salvage homogeneity formally by postulating $a d-h o c$ asymmetric real fixed costs of changing money wages (asymmetric menu costs), but Tobin would have regarded that as spurious micro-foundations. As a practical policy issue the existence of a non-vertical long-run Phillips curve does not matter much. For stabilisation purposes, all that is required is that there be a stable trade-off for long enough to enable policy to boost or weaken aggregate demand.

Tobin had a visceral dislike of the term 'natural rate of unemployment'. Like George Orwell, and unlike Humpty Dumpty, he believed that words matter. ${ }^{35}$ Calling something the 'natural' rate of unemployment implied that any other rate would be 'unnatural'. Normative and positive connotations become tangled up and make for

\footnotetext{
${ }^{34}$ With full pass-through, there is no vertical long-run Phillips curve.

${ }^{35}$ In Lewis Carroll's Through the Looking Glass, Humpty Dumpty says to Alice, "When I use a word...it means what I choose it to mean - neither more nor less." "The question is," said Alice, "whether you can make words mean so many different things." "The question is," said Humpty Dumpty, "which is to be master - that's all" (Caroll [1871]).
} 
undisciplined discourse and distorted or even dishonest policy advice. Since many economists alternate frequently between technical, academic discourse and policy advice and advocacy, it behoves us as a profession to pay greater attention to the fact that the words we use professionally have a meaning and life of their own outside the narrow confines of scholarly discourse. Tobin alternated between using terms like NAIRU (Non-Accelerating Inflation Rate of Unemployment) ${ }^{36}$, or 'inflation-safe' rate of unemployment. It was a losing battle. He continued to use the concept of 'involuntary unemployment' to emphasize the difference between unemployment and holidays and vacations. The Great Depression was not the Long Vacation. The value of the output foregone was not compensated for by the value of the leisure gained, and the difference was not just due to labour income taxes. Coasian bargains are difficult to strike in fragmented labour markets with two-sided asymmetric information, in which players will interact with each other on only a finite number of occasions, in which bargaining is costly, external enforcement of contracts is limited, and insufficient trust or reputation exists to support non-cooperative yet efficient outcomes.

As regards financial market incompleteness and inefficiency, a key source of incompleteness is the limited extent to which human wealth (future after-tax wage income) can be mobilised to support current consumption spending. As a result, with labour income between two thirds and three quarters of national income in modern industrial economies, most household wealth is highly illiquid. Liquidity constraints should therefore characterise the optimal consumption plan of many households, especially those with 'permanent income preferences' and a rising age-earnings

\footnotetext{
${ }^{36}$ Bemused undergraduates used to wonder how the late Indian Prime Minister Nehru could possibly have given his name to the equilibrium rate of unemployment.
} 
profile. ${ }^{37}$ Tobin's work, much of it joint with Walt Dolde, on realistic permanent income/life cycle models with liquidity constraints that bind at certain points in the life cycle represents an important and methodologically innovative attempt to determine the empirical significance of liquidity constraints (Tobin and Dolde [1971, 1976], Dolde and Tobin [1983]).

Even in those financial markets that are technically efficient, like the US stock market, the foreign exchange markets and the government debt markets, Tobin saw frequent departures from efficiency in the less restricted senses of the word. ${ }^{38} \mathrm{He}$ accepted that financial markets possessed what he called information arbitrage efficiency' (Tobin [1984]), that is, that they were informationally efficient in the weak and semi-strong sense. You can not systematically make money trading on the basis of generally available public information. He did not believe that financial markets consistently possessed 'fundamental valuation efficiency': financial asset prices do not necessarily reflect the rational expectations of the future payments to which the asset gives title (Modigliani and Cohn [1979], Shiller [1979, 1981, 1999, 2000], and Brainard, Shoven and Weiss [1981]). Key financial markets, including the stock market, the long-term debt market and the foreign exchange market are characterised both by excess volatility and persistent misalignments, that is, prices deviating persistently from fundamental valuations.

Tobin also contested the notion that the financial markets delivered 'value for money' in the social sense. “...the services of the system do not come cheap. An immense amount of activity takes place, and considerable resources are devoted to

\footnotetext{
37 'Permanent income preferences' is shorthand for preferences characterised by a low elasticity of intertemporal substitution; consumers with such preferences suffer a considerable welfare loss from constraints on their ability to smooth consumption over the life cycle.

${ }^{38} \mathrm{~A}$ market is technically efficient if it is liquid and competitive, that is, it is possible to buy or sell large quantities with very low transaction costs, at little or no notice and without a significant impact on the market price.
} 
it." (Tobin [1984, p. 284]). Tobin referred to this aspect of efficiency as 'functional efficiency'. Finally, the system of financial markets can be efficient in the technical, information arbitrage, fundamental valuation and functional senses without possessing what Tobin called Arrow-Debreu full insurance efficiency, that is, without supporting Pareto-efficient economy-wide outcomes. ${ }^{39}$ The reason is that real world financial markets interact with labour and goods markets that are inefficient in every sense of the word. This scepticism about the efficiency of financial markets was no doubt among the considerations that led him to advocate a Tobin tax on foreign exchange market turnover (see Section 7).

Establishing that there are significant and persistent occurrences of market failure in labour, product and financial markets, does not constitute a case for the active use of stabilisation policy. It must also be established that measures aimed at directly targeting the distortions or other factors that cause these market failures are not effective or infeasible for technical or political reasons. The illiquidity of human wealth and the poor collateral value of future after-tax wage income are due to two factors: asymmetric information and free labour laws. The first of these factors can be mitigated but not eliminated. The second we are happy to live with - there have been no calls for the restoration of slavery and indentured labour, or for the removal of restrictions on the ability of workers to post bond. As regards the failure of labour markets to clear, Tobin viewed insufficient or excess demand for goods and services as the proximate and prime determinant of inadequate demand for labour. Demand management was therefore the appropriate form of policy intervention.

Much of the debate about monetary and fiscal policy effectiveness Tobin was engaged in concerned the effects of monetary and fiscal policy on aggregate demand.

\footnotetext{
${ }^{39}$ The financial market system possesses what Tobin called 'full insurance efficiency' if it enables economic agents to insure for themselves deliveries of goods and services in all future contingencies. In that case, the system of financial markets is equivalent to a complete set of Arrow-Debreu markets.
} 
It did not concern the important but quite separate question as to whether an increase in nominal aggregate demand would be translated into an increase in the general price level, an increase in real output or some combination of the two. In Section 8.2, I shall review Tobin's contribution to the debate on the influence of monetary and fiscal policy on aggregate demand. In Section 8.3 the joint determination of aggregate quantities and prices will be considered. Like virtually all American economists of his generation, Tobin used a closed economy framework for most of his macroeconomic research. ${ }^{40}$

\subsection{The Influence of Monetary and Fiscal Policy on Aggregate Demand}

During the forties, fifties and sixties, Tobin wrote a number of important theoretical and empirical papers on the interest-sensitivity and stability of the demand for money (Tobin [1947b, 1956, 1958b, 1965b], Tobin and Swan [1969]). These papers are part of a long-running scholarly debate between Milton Friedman and Tobin (Friedman [1956, 1959, 1968, 1969, 1971], Friedman and Schwartz [1963]). Oversimplifying slightly, Friedman's position was that fiscal policy was ineffective (did not influence aggregate demand) and that monetary policy was effective, even powerful, but unreliable and not suitable as an instrument for actively stabilising the real economy.

\section{2a. Monetary policy rules}

Friedman recognised that monetary policy was a key driver of nominal income and that in the short run monetary policy could have strong effects on real output and employment. Indeed the monumental empirical investigations conducted by

\footnotetext{
${ }^{40}$ His contributions to open economy macroeconomics include Tobin and de Macedo [1980], Tobin and Brainard [1992] and a number of other publications reprinted in Tobin [1996b, Section IV].
} 
Friedman and his collaborators and associates established to their satisfaction if not to Tobin's, that variations in nominal money growth (viewed as exogenous and causal) played a dominant role in driving changes in nominal GDP growth and, in the short run, also of movements in real GDP growth. Other potential drivers of nominal and real GDP growth, such as fiscal policy, played at most a subordinate role (see e.g. Friedman and Schwarz [1963] and Friedman [1956, 1969]). Friedman therefore found himself in the prima facie rather uncomfortable position of arguing both that money is uniquely powerful as a determinant of nominal and real income growth in the short run and of inflation in the long run, and that it should not be used to try to stabilise the real economy.

Tobin, a sophisticated methodologist of both economics and econometrics, was unimpressed by the accumulation of evidence by Friedman, Schwarz an others on the timing (leads and lags) of turning points in monetary growth and nominal income growth. His "Post-Hoc Ergo Propter Hoc" paper (Tobin [1970a]) is a classic and devastating demonstration of the point that timing does not imply causation - a point that is as obvious as it is frequently forgotten. Using an ultra-Keynesian model (interest-insensitive investment, no wealth effect and therefore no Pigou or real balance effect on consumption, a fixed price level and a monetary policy rule that fixes the interest rate and therefore implies a passive, endogenous money stock) Tobin reproduces all the leads and lags at cyclical turning points between money and national income that Milton Friedman and Anna Schwartz had offered in support of their thesis that changes in the supply of money are the principal cause of changes in nominal income. While Tobin's model is deterministic, more recent stochastic or 
statistical varieties of the Post-Hoc Ergo Propter Hoc fallacy (the confusion of correlation, timing and causation) can be exposed using similar arguments. ${ }^{41}$

Friedman resolved the paradox of maintaining both that money was uniquely powerful and that it should not be used for stabilisation purposes, by arguing that monetary policy is too powerful and unpredictable to be used by fallible and often self-serving mortals. The magnitude and timing of the effects of monetary policy on both real and nominal variables are highly uncertain (Friedman's long and variable lags). Unless monetary policy management was unrealistically competent and benevolent, activist attempts to smooth the business cycle might well turn out to be destabilising. As the decades passed, Friedman's position on the ability of monetary policy to have any systematic effect on any moment of the distribution function of real output converged with that of the 'monetary policy ineffectiveness' views of the New Classical macroeconomist, like Lucas, Sargent and Barro (see e.g Friedman [1968], Lucas and Rapping [1969], Lucas [1976, 1981b], Sargent and Wallace [1975], Barro [1976]).

Friedman's monetary policy prescription was for the simplest noncontingent rules: a free float for the exchange rate and a constant growth rate for some nominal aggregate. At first, the choice of the appropriate monetary aggregate whose growth rate was to be targeted by the monetary authorities using the actual instruments of government policy (if the exchange rate floats, either a short nominal interest rate or base money ${ }^{42}$ ) may have looked like a minor technical issue. However, in the US, the UK and everywhere monetary targeting was tried, the income velocity

\footnotetext{
${ }^{41}$ Learning is a slow process in our profession and what little is learnt can be forgotten again (and again), as is evident from the near-ineradicable practice of attributing a causal interpretation to statistical tests of incremental predictive content like the so-called Granger Causality tests (see Granger [1980]).

${ }^{42}$ In the US, policy is formulated in terms of the behaviour of commercial banks' reserves with the central bank rather than the monetary base, but the distinction is not substantive.
} 
of circulation of the monetary aggregate proposed as an appropriate nominal anchor turned out to be both highly variable and unpredictable. Goodhart's Law ('An indicator is useful until it becomes a target') struck with a vengeance (Goodhart [1984, p. 96]). This variant of the Lucas Critique held that any monetary aggregate designated a target by the monetary authorities would ipso facto shed previously established empirical regularities. The monetary authorities and the scholars favouring monetary targeting were led on a merry chase that went from M1 to M1a, M1b, M2, M3 and M4 and may well have been headed for M16 and AK47. Ultimately, the prospect of monetary aggregates with two-digit numerical indices became too much and monetary targeting died of natural causes. As the former head of the Central Bank of Canada, Governor Gerald Bouey put it, "We did not abandon M1, M1 abandoned us."43

A common feature of the velocity of circulation of all monetary aggregates since the 1970's has been their variability and unpredictability. Far from this being an argument against the use of monetary policy for stabilisation policy, this represents a case for using the short nominal interest rate as the instrument of monetary policy rather than some monetary aggregate. This of course is what monetary authorities have always done, when they were not operating a fixed exchange rate regime. ${ }^{44}$ I know of no monetary authority that has used a monetary aggregate (even the monetary base) as the instrument of policy. There have been differences in the intermediate target(s) pursued with the use of the interest rate instrument. For a while, under Paul Volcker during 1981-82, the Federal Reserve targeted monetary aggregates, an experiment that was discontinued after two years. Today many

\footnotetext{
${ }^{43}$ Canada, House of Commons [1983]. There are other versions of this quote about, including: It was Governor Gerald Bouey of Canada at the time who made the famous statement: "In Canada, we did not abandon money supply targets, they abandoned us". BIS Review [1997].

${ }^{44}$ In practice, even a fixed exchange rate regime will involve the use of the short nominal interest rate as a supporting policy instrument.
} 
monetary authorities use the interest rate instrument to pursue medium term inflation targets while attempting, without too much prejudice to the inflation target, to keep real economic activity close to estimated normal or capacity levels. One can agree, as did Tobin, that the transmission of monetary policy was subject to long, variable and uncertain lags without concluding from that that the appropriate response is a constant target growth rate for some monetary aggregate. Indeed a constant growth rate for the monetary target may well be as destabilising as a constant nominal interest rate (see e.g. McCallum $[1988,1999]){ }^{45}$

A Taylor-type rule to dampen normal cyclical fluctuations, and a readiness to do much more in the event of a catastrophic loss of confidence by financial market participants, consumers and businesses provide a reasonable summary of Tobin's practical monetary policy prescriptions. Friedman's prescription of a constant growth rate for some monetary aggregate is completely out of favour today with both economic theorists and monetary policy makers, and has been for at least a couple of decades. Monetary feedback rules are the only game in town. While its lack of support does not constitute proof that Friedman's prescription is wrong, Tobin must have derived some satisfaction from the overwhelming acceptance of the kind of activist monetary policy rule he had been advocating for most of his professional life.

\section{2b. The effectiveness of fiscal policy for demand management}

\section{The interest elasticity of money demand}

Fiscal policy (or anything else) will be unable to influence the level of aggregate demand if the income velocity of circulation of money is constant and the

\footnotetext{
${ }^{45}$ A constant nominal interest rate policy tends to give rise to Wicksellian instability, with the real interest rate rising or falling without bound. The Taylor rule is a simple mechanism for ruling out Wicksellian instability in a wide class of models.
} 
monetary authorities peg the nominal quantity of money (if the LM curve is vertical). It will, of course, affect the composition of aggregate demand between private and public consumption and investment (and in an open economy, also net exports) even when the level of aggregate demand is unchanged.

The conclusion from Tobin's key papers on the interest sensitivity of money demand (Tobin $[1947 b, 1948,1956,1958 b])$, that there was an economically and statistically significant interest-responsiveness of money demand were a necessary part of Tobin's argument that there was a distinct role for fiscal policy in stabilisation policy.

His paper on the transactions demand for money using an inventory-theoretic approach (Tobin [1956]), contained (and generalised) the now famous square root rule for money demand which, unbeknownst to Tobin, had been derived and published earlier by Baumol [1952]. Unbeknownst to both Tobin and Baumol, this result had been derived and published even earlier by Maurice Allais [1947]. Following the award of the Nobel Prize to Allais, Baumol and Tobin [1989] wrote a gracious note acknowledging his priority. ${ }^{46} 47$

The title of the paper that started modern portfolio theory, "Liquidity Preference as Behaviour Towards Risk", (Tobin [1958b]) suggests that Tobin derived the portfolio separation theorem as a by-product of an attempt to establish stronger analytical foundations for the interest-sensitivity of the demand for money. It is, however, clear that the mean-variance approach to portfolio selection fails as a theory of the demand for money in the narrow sense, that is, the transactions medium or cash.

\footnotetext{
${ }^{46}$ This episode illustrates two points. First, the importance of having a competent graduate student to do a literature search. Second, the problems encountered by economists working outside the United States in having the priority of their work acknowledged in the United States, especially if that work has been published in a language other than English.

${ }^{47}$ Allais [1947] also contains the first formal exposition of the overlapping generations model, an achievement often still credited to Samuelson [1958] by many.
} 
Mean-variance theory can explain the division of a portfolio between risk-free and risky assets. It cannot motivate the demand for narrow money, that is, non-interestbearing cash, which is rate of return dominated as a store of value, because there are other assets (government bills) that have a positive nominal return in each state of nature.

\section{Long-run financial 'crowding out'}

Having lost the argument about the interest-sensitivity of money demand, Friedman shifted the debate about the effectiveness of fiscal policy to different ground (Friedman [1970, 1971, 1972], Tobin [1970a, c; 1972b]. The ineffectiveness of fiscal policy is no longer due to the instantaneous financial crowding out caused by a vertical LM curve, but rests on long-run financial crowding out. The accumulation of public liabilities associated with debt-financed government deficits will ultimately drive up interest rates and crowd out interest-sensitive private spending to the point that there will be no impact left on aggregate demand from expansionary public spending increase or tax cut. ${ }^{48}$ This proposition prompted a rash of papers analysing the long-run effect of fiscal policy on aggregate demand when the government debt stock is endogenised through the government budget constraint (e.g. Christ [1968], Blinder and Solow [1973], Friedman [1978], Sargent and Wallace [1981]). Tobin made a number of contributions to this literature and I was priviliged to be a junior co-author in a couple of them (Tobin [1979], Tobin and Buiter [1976, 1980]).

With financial wealth (including private holdings of public debt) an argument both in the consumption function and in the money demand function, the effect of bond-financed deficits financing is to shift the LM curve up and to the left and the IS

\footnotetext{
${ }^{48}$ With a Keynesian consumption function, the balanced budget multiplier makes the effect of a balanced budget increase in public spending expansionary. Friedman, of course, preferred the permanent income theory of consumption.
} 
curve up and to the right in nominal interest rate-output space as long as the deficit persists. Full crowding out of the effect of a public spending increase or a tax cut on aggregate demand is theoretically possible but not empirically likely, even in steady state.

\section{Debt neutrality}

At around this time, Friedman detached from the scholarly fiscal policy effectiveness debate. The next key development was the resurrection of debt neutrality or Ricardian equivalence by Robert Barro [1974]. Tobin had written on the subject as early as 1952 (Tobin [1952a]). Section 3.3 'The Public Debt as Private Wealth' contains the passage. "The inclusion of the interest-bearing public debt in net private balances and in total private wealth raises an interesting question. How is it possible that society merely by the device of incurring a debt to itself can deceive itself into believing that it is wealthier? Do not the additional taxes which are necessary to carry the interest charges reduce the value of other components of private wealth? There certainly must be effects in this direction. Additional taxes on the returns from income-producing property reduce, at a given rate of discount, the present value of that property."

The simplest and strongest version of the debt neutrality proposition holds constant the sequences of real public spending on goods and services and of monetary issuance and considers the consequences of postponing taxes without changing the present discounted value of current and future taxes; the government therefore continues to satisfy its intertemporal budget constraint. Taxes are lump sum.

Tobin argued that postponing taxes by borrowing would only boost consumption demand under two sets of conditions. Either private agents are myopic 
and do not allow for the higher future taxes implied by the current tax cut, or private agents are not myopic, do allow for the fact that the present value of current and future taxes is the same, but postponing taxes redistributes (current and/or future) resources from consumers with low marginal propensities to spend to consumers with higher marginal propensities to spend (see e.g. Tobin and Haliassos [1990]). There may be many reasons in addition to the differences in life expectancy between the young and the old and the differences in spending propensities of those currently alive and the unborn emphasised by the simple OLG life cycle model why borrowing by governments may affect aggregate consumption demand. The government may, for instance, be able, by changing the timing of taxes, to do for some (liquidity) constrained individuals what they cannot do for themselves. ${ }^{49}$

Clearly, with a forward-looking representative agent model of consumption and portfolio allocation (finite or infinite-lived), there will always be debt neutrality because one cannot redistribute among identical agents. The OLG model without intergenerational gift motives has the minimum amount of consumer heterogeneity required to support the absence of debt neutrality. ${ }^{50}$ Barro's version of the finite horizon OLG model with an intergeneration bequest or gift motive supports equilibria for which the intergenerational gift motive is operative (the non-negativity constraint on bequests is not binding for any generation). In such equilibria, the infinite sequence of finite-lived overlapping generations becomes equivalent to a single infinite-lived representative agent. There will be debt neutrality for small debt financed tax cuts. If the intergenerational gift motive is either absent or non-operative,

\footnotetext{
${ }^{49}$ Note, however, that it remains necessary that there be some heterogeneity among households at a point in time for this to work. If everyone is liquidity-constrained, the government cannot cut taxes and borrow, because there will be no-one to purchase the additional public debt. So, in order to be able to redistribute disposable resources for the same consumer at different points in time, it must be possible to redistribute among consumers at a point in time.

${ }^{50}$ This is true even if each generation is infinite-lived and if all generations are taxed the same. All it requires is 'new entrants', that is, a positive birth rate. See e.g. Buiter [1988].
} 
postponing taxes will (if future taxes either fall equally on young and old or more heavily on the young) amount to redistribution from the young to the old or from unborn future generations to generations currently alive. Both kinds of redistribution will boost aggregate consumption.

For the postponement of taxes to boost consumption it is important, as Tobin points out in the quotation given above, that the postponed taxes not be taxes on the returns from income-producing assets that are owned by households alive at the time of the tax reduction. If the tax is a land tax, say, and if the land market is efficient, a tax cut that preserves the present discounted value of current and future taxes will leave unchanged the current value of the land and the consumption of its owners. Taxes on labour income are the natural example of taxes that do not get capitalised in this way, at least not since the abolition of hereditary slavery.

Not surprisingly, strict Ricardian equivalence is not supported by the data (see e.g. Elmendorf and Mankiw [1999]). Debt financed tax cuts that do not affect the market's assessment of the government's ability and willingness to satisfy its intertemporal budget constraint will boost consumption and aggregate domestic demand.

The debate about the ability of fiscal policy to influence aggregate demand is on-going and has dealt with issues that were not a primary concern of Tobin. For instance, even if Ricardian equivalence holds, there remain fiscal policy actions that affect aggregate demand. In the infinite-lived representative consumer model with complete markets, a temporary increase in government consumption spending raises aggregate demand unless government consumption is a perfect substitute for private consumption in the private utility function. Money-financed tax cuts or spending increases will likewise boost aggregate demand in a world with Ricardian equivalence. 
Stimuli to private investment such as a temporary investment tax credit or a temporary investment subsidy affect investment spending through the neoclassical channel of altering the intertemporal terms of trade. So will temporary (and revenue-neutral) changes in the pattern of VAT and other indirect tax rates over time, and temporary (revenue-neutral) changes in labour income taxes and social security contributions. This takes us quite a long way from conventional fiscal stabilisation policy, however.

\subsection{Aggregate Demand Meets Aggregate Supply}

Tobin's view of how aggregate demand interacts with the supply side of the economy to produce equilibrium quantities and prices, including asset prices and rates of return, varies over time and across different contributions written at roughly the same point in time. Thanks to some of the later, more reflective writings of Tobin (especially Tobin [1983b, 1992b, c, 1993, 1995]) I have been able to put together a portmanteau schematic that may help bring out the underlying order that I believe is there.

I interpret Tobin's view of the ways in which demand management policy can influence actual employment or output as follows: $A$ denotes real aggregate demand, $Y$ actual output, $Y^{N}$ the natural level of output (that is, the level of output produced by the natural level of employment) and $Y^{F}$ the full information level of output. To save on notation, $Y, Y^{N}$ and $Y^{F}$ will, when there is no risk of confusion, also be taken to stand for the actual, natural and full information levels of employment. Full information output is the level of output (not necessarily unique or independent of aggregate demand) that would prevail if there were no perception and forecast errors. The natural level of output (employment) is that level (probably unique and independent of aggregate demand at a point in time, although possibly hysteretic or 
path-dependent in the long run) at which every worker who wants to work is employed at the prevailing wage. ${ }^{51} 52$ Tobin would have preferred to call this full employment and the full employment level of output. $E_{l}$ is the expectation operator conditional on information available at time $l$. By definition,

$$
Y \equiv Y^{N}+\left(Y^{F}-Y^{N}\right)+\left(Y-Y^{F}\right)
$$

For macroeconomic models to exhibit the strong New Classical policy ineffectiveness properties (only unanticipated policy matters for real output and employment), three features must be present: (A1) $Y^{F}=Y^{N}$ : the natural and full information levels of output are the same; (A2) The natural rate is unique and independent of aggregate demand; (A3) $E_{t-j}\left[Y(t)-Y^{F}(t)\right]=0, j \geq 0$ : perception or forecast errors don't have a systematic component. This last property would be an implication of rational expectations.

The Friedman-Lucas-Rapping "surprise" or "misperceptions" supply function (Friedman [1968], Lucas and Rapping [1969]), according to which actual output or employment differ from their natural values only if the there are price surprises (misperceptions or forecast errors) is an example of (A1) and (A2) holding.

Formally, however, the Lucas-Rapping model is an intertemporal substitution model of labour supply, in which labour supply is driven by the value of the current real wage relative to the present discounted value of the future real wage. In this model, the full-information supply of labour and the full information levels of employment and output could be affected by anticipated monetary (or fiscal) policy, if anticipated monetary (or fiscal) policy were to have an effect on the real interest rate. Absence of superneutrality of money can be a feature of monetary general equilibrium

\footnotetext{
${ }^{51}$ Even at a point in time, the natural rate could depend on structural features of the labour and product markets, including monopoly and monopsony power, unemployment benefits, income tax rates etc. ${ }^{52}$ It will be unique at a point in time if labour supply and demand are independent of the real and nominal rates of interest.
} 
models as diverse as Tobin [1965a, 1968b, 1986a], Sidrauski [1967], Lucas [1972] and Fischer [1979]). In this more general version of the misperceptions supply function, (A2) does not hold: the full information/natural levels of output and employment can be influenced by monetary and fiscal policy. However, such channels of policy effectiveness bear little relation to conventional stabilisation policy.

The combination of the Friedman-Lucas-Rapping surprise supply function with the rational expectations hypothesis (A3), which implies that there are no systematic forecast errors, means that policy rules cannot influence the first moment (conditional or unconditional) of the distribution of output and employment (Sargent and Wallace [1975], Lucas [1976], McCallum [1979]). Even then, it may be possible for deterministic policy feedback rules to influence the conditional and unconditional second moment of output and employment (see Turnovsky [1980] and Buiter [1981]).

Tobin rejected all three key assumptions necessary for the policy ineffectiveness proposition, although he considered (A2) not very important for the design and implementation of stabilisation policy. He believed that even with rational expectations (that is, with $\mathrm{A}(3)$ holding), policy could influence the full information levels of employment and output (that is, (A1) need not hold).

Tobin also believed that the augmentation term in the Phillips curve represented more that just expected inflation and preferred to refer to it as 'core inflation', a concept developed by Otto Eckstein [1981] and Arthur Okun [1981]. Core inflation represents anything that imparts inertia to the price and wage determination process, be it adaptive or other mechanically backward-looking price expectation formation, long-term incomplete nominal wage or price contracts, backward-looking wage-indexation or anything else. Formally we can see this as a rejection of (A3). 
Tobin was both amused and bemused that the much-criticised ad-hoc, backward-looking, mechanical expectation formation models of the early 1960s (such as adaptive expectations) made a comeback in the 1980s and 1990s in the guise of adaptive learning rules (see e.g. Bray [1982], Evans [1983], Marcet and Sargent [1989], Dawid [1996], Sargent [1993], Marimon [1997] and Evans and Honkapohja [2001]). ${ }^{53}$ This reincarnation illustrates two points. First, ideas and theories in economics frequently vanish and subsequently re-appear in a form characterised invariably by enhanced analytical complexity but only occasionally by additional fundamental insight. Second, as soon as the camel of bounded rationality gets its nose in the tent of rational expectations equilibrium economics, behaviour emerges that fits Tobin's Keynesian world view remarkably well.

Many of the small analytical macroeconomic models analysed by Tobin in his papers and lecture notes treat output and employment as demand-determined, with no appeal to misperception or forecasting errors (e.g Tobin [1993]). One way of characterising a Keynesian short-run or temporary equilibrium would be $A=Y=Y^{F}<Y^{N} \cdot{ }^{54}$ Tobin never provided a complete model generating such a temporary equilibrium from optimising first principles, but he was sympathetic to the co-ordination failure approaches of e.g. Weitzman [1982], Bryant [1983] and Cooper and John [1988]. A different Keynesian temporary equilibrium is supported by Phillips curve models with sluggish core inflation (in the New Classical interpretation, a surprise supply function with non-rational expectations). The natural interpretation

\footnotetext{
${ }^{53}$ A striking recent example is Selgin [2003]. In a paper on adaptive learning and the transition to fiat money, adaptive learning turns out to mean static expectations (the present and future are expected to be like yesterday). In addition, Ellison and Fudenberg [1993] are credited as the source of this static expectations 'rule of thumb'. It is further evidence of the immaturity of economics as a science that an appeal to higher authority (Marx, Keynes, Lucas etc.) is often considered an acceptable substitute for empirical evidence or logical argument starting from reasonable primitive assumptions.

${ }^{54}$ To keep the taxonomy tractable, I include in this specification the models that permit aggregate demand to differ from real output, $A \neq Y$, treat real output as predetermined, and make the rate of change of output a function of the gap between $A$ and $Y$ (see e.g. Tobin [1975b]).
} 
of such models is that $A=Y$ and $Y^{F}=Y^{N}$, with $Y^{N}$ exogenous, but that (A3) is not satisfied: deviations of actual output from the natural level of output are non-random and can be influenced by systematic policy rules. Tobin's papers with Phillips curves and sluggish core inflation fit into this category (e.g. Tobin [1967b, 1968a, 1972a, 1973a, 1975b], Tobin and Buiter [1980]).

\subsection{Can Our Institutions and Policy Makers Deliver Good Stabilisation Policy?}

Tobin's arguments that (1) monetary and fiscal policy can systematically affect aggregate demand and (2) variations in aggregate demand have a systematic effect on aggregate output and employment, at least in the short run, do not suffice to make the case for active stabilisation policy. The case remains to be made that our political system will elect or appoint policy makers that have the capability and the willingness to pursue wellbeing-enhancing stabilisation policy. Here Tobin was an unreconstructed optimist. His own experience on the Council of Economics Advisers during the Kennedy years (1961-62) confirmed his belief - perhaps his faith - that the economics profession had developed the tools to stabilise the economy and that policy makers could be convinced to use them. At one level, he recognised that the factors that cause market failure (e.g asymmetric information, the inability to make binding commitments, transaction costs, non-rivalness in use, non-excludability) are often the same factors that cause government failure, including the failure of government policies intended to address the market failure. Nevertheless, he kept coming up with plans and proposals to improve the performance of markets and other economic institutions. Despite many disappointments about economic policies and policy makers in the forty years after he left the Council, this optimism about man's ability to improve the working of the economy, and the material foundations of the quality of 
life in general, never left him. 'Social engineer' was not a term of opprobrium to Tobin (Tobin [1986b, 1990b]).

\section{Methodology: Microfoundations, Aggregation and Deep Structural Excavation}

Macroeconomics, the study of the economy as a whole, tries to establish relationships between aggregate economic variables, economy-wide prices and policy instruments, that are stable ('invariant') under the kinds of shocks and interventions the macroeconomic modeller is interested in analysing. Where do (or should) we economists find the behavioural hypotheses that shape the models use to understand the world around us and to predict the future? I believe Tobin's answer to be: anywhere insight may be found. While this answer is not an operational guide, it underlines Tobin's life-long openness to old and new approaches and his nondogmatic willingness to let 100 flowers bloom.

Tobin's introduction to the first volume of his collected essays (Tobin [1971]) hits the nail right on the head: "Although macroeconomic models do not pay explicit attention to the internal composition of the aggregates, the relationships among aggregate variables that make up the models are intended to be consistent with theoretical and empirical knowledge of the behavior of individual economic units and particular markets."... “Unfortunately it is seldom true that an exact relationship among aggregate variables, independent of their composition, can be built up from the basis microeconomic relationships. The usual procedure is simple analogy, but it is not clear that this is always the best approximation. Although there is a theory of aggregation, so far it gives little guide to the optimal specification of aggregate 
variables and relationships. Fortunately this logical gap does not seem to be of decisive practical importance." (Tobin [1971, pp. viii-ix]). ${ }^{55}$

Note that Tobin refers to the 'behavior of individual economic units', not to the optimising behaviour of individual economic units. Tobin was not wedded to the notion that constrained optimisation was the only permissible way to generate decision rules or other characterisations of individual behaviour, like Eulerequations. ${ }^{56}$ Where he deemed it the best tool for addressing the issue at hand (e.g. intertemporal choice in the life-cycle model) Tobin used constrained optimisation approaches to household and firm behaviour freely and expertly. Where constrained optimisation yielded no insight at best and at worst did no more than obscure our ignorance about the fundamental roots of a phenomenon (e.g. nominal rigidities, the demand for money), he directly postulated decision rules with properties that made sense based on empirical observation, introspection or a sudden flash of insight.

For Tobin, individual rational behaviour was not synonymous with optimising behaviour. ${ }^{57}$ Regardless of the derivation of the individual decision rules, aggregate behaviour was most unlikely to look like a (positive) scalar blow-up of individual

\footnotetext{
${ }^{55}$ The contrast with the views of Robert E. Lucas [1980 and 1981, p. 290] on this issue is striking: "...it is the hypothesis of competitive equilibrium which permits group behaviour to be predicted from knowledge of individual preferences and technology without the addition of any free parameters." As will be clear from Footnote 60 and the remainder of this Section, I consider this position of Lucas to be untenable.

${ }^{56}$ Within the constrained optimisation church, methodological individualism, and the further restriction of the individual consumer's concerns to the space of his own consumption of goods and services, constitute further sectarian divisions. Tobin's approach was to go for the simplest a-priori plausible set if behavioural assumptions that permitted light to be shed on the issue(s) under consideration.

${ }^{57}$ I use the expressions "optimising behaviour" or "individual decision rules derived from constrained optimisation" as shorthand for constrained optimisation with unbounded rationality (no limits on understanding, comprehension and on computational, data gathering and processing capacity) and rational expectations. Rational expectations here mean Bayesian predictions, where the subjective conditional joint distribution function of past, current and future variables of interest is the same as the true (objective or frequentist) conditional joint distribution function. I recognise that the most general Arrow-Debreu state-space version of the competitive general equilibrium model dispenses altogether with both subjective and frequentist notions of probability; in addition, even when the mathematical characterisation of the economy involves either subjective or frequentist notions of probability, von Neumann-Morgenstern expected utility does not exhaust the universe of possible characterisations of household behaviour under uncertainty.
} 
behaviour. Equilibrium was not restricted to competitive equilibrium. There were many competing equilibrium concepts, and the appropriateness of any given equilibrium concept depended on the application under consideration. ${ }^{58}$

As regards individual rationality, Tobin required that rational economic agents operating in a market economy with credible contract enforcement satisfy (or, in models with incomplete markets and incomplete contracts, plan to satisfy) their budget constraints and/or balance sheet constraints. ${ }^{59}$ Their decision rules do not exhibit money illusion (homogeneity of degree zero of all real quantities and relative prices in all nominal prices and nominally denominated endowments). Additional restrictions on individual decision rules (and a fortiori on aggregate behavioural relationships) could, but need not, be derived from individual optimising behaviour. Aggregate excess demand functions satisfy Walras' Law and (where appropriate) the balance sheet constraint as well as absence of money illusion. Beyond that, theory may not help much; constructive and creative ad-hoccery is called for. $^{60}$

\footnotetext{
${ }^{58}$ The concept of 'equilibrium' in economics has become progressively less restrictive and now accommodates many states, outcomes or configurations that would in the past have been described as disequilibria. When stationary or steady-state equilibria were augmented with temporary or monetary equilibria, equilibrium ceased to have the connotation of 'state of rest'. Lucas and Sargent [1978 and 1981, p. 304], identify an equilibrium model as one which has the property "(a) that markets clear and (b) that agents act in their own self-interest". With quantity rationing now a familiar feature even of models with optimising agents, 'market clearing' has become a vague, if not vacuous concept. Property (b) of Lucas and Sargent appears to impose two requirements. First, aggregate behaviour must be derived from the explicit aggregation of individual behaviour; second, individual behaviour must be derived from constrained optimisation. Tobin would have accepted neither requirement as necessary ingredients of an equilibrium model. Today 'equilibrium' means no more than 'fixed point of some mapping one is comfortable with'.

${ }^{59}$ With incomplete markets/contracts, default and bankruptcy become a possibility if the budget constraint is violated ex-post.

${ }^{60}$ The years I was a graduate student at Yale, 1971-75, saw the publication of some important papers that demonstrated that the Arrow-Debreu general equilibrium model was effectively void of empirical content; specifically, the market excess demand functions of the Arrow-Debreu general equilibrium model (which are obtained by summing individual excess demands obtained from competitive optimising behaviour) satisfy continuity, homogeneity of degree zero (absence of money illusion) and Walras' Law - and that's about it (Sonnenschein [1973, 1974], Mantel [1974], Debreu [1974]). I became aware of these results through my work as Tobin's Teaching Assistant in the graduate macroeconomics course 1973-4, rather than through any of the formal general equilibrium courses I attended.
} 
I never got the impression, either from his writings or from conversations, that Tobin considered the absence of optimising microfoundations prima facie evidence of a second-best or faute de mieux research strategy. I would go as far as suggesting that that Tobin considered optimising microfoundations to be no less 'second-best than a number of behavioural alternatives. The unbounded rationality of the Bayesian constrained optimiser (even without fully rational expectations) represents a heroic, extreme, indeed unreasonable assumption, justifiable only if it is uniquely useful for generating insight and/or interesting testable predictions. Bounded rationality (like 'rational learning') if not an oxymoron, is close to an empty box. Economists and other behavioural scientists frequently look like the proverbial blind man searching in a dark basement for a black cat that isn't there. Methodological modesty is called for.

Tobin's non-dogmatic approach to economic methodology is reflected in his interest in broader behavioural and psychological approaches to economic behaviour (Tobin and Dolbear [1963]) and in Katona's survey-based work on the predictive value of consumer intentions and attitudes (Tobin [1959]). Tobin's critical interest in the evolutionary approach of Nelson and Winter [1982] and the transaction cost economics of Williamson [1987], and his interest in and support of the work of Shiller $[1999,2000]$ and of behavioural finance in general, also bear this out. ${ }^{61}$

What Tobin objected to strongly is what I shall refer to as 'spurious' or 'pseudo' microfoundations, although Tobin did not, as far as I know, use this characterisation in writing. Spurious micro foundations result from the optimisation of a poorly motivated objective function subject to a set of a-priori or empirically implausible constraints. The choice of the unfortunate objective function and the regrettable constraints is motivated solely by the desire to generate a decision rule

\footnotetext{
${ }^{61}$ Nelson, Winter, Williamson and Shiller all were colleagues of Tobin at Yale.
} 
involving observables that fits some restricted set of stylized facts. Little or no attention is paid to the fact that most of the time the pairing of objective function and constraints under consideration has further implications that are clearly counterfactual (see e.g. Tobin [1983b, 1987, 1992b, c, 1993, 1995, 1996a]). ${ }^{62}$

Tobin's view on aggregation was pragmatic. There is no hard or fast rule as to whether it is better to derive aggregate behaviour through the aggregation of the behaviour of individual units or by postulating relationships directly at the level of the aggregates. Aggregation theory does not help much, as it makes clear that the aggregate behaviour obtained through the explicit aggregation of individual behaviours can only very rarely be expressed solely as a relationship between the aggregates. ${ }^{63}$ As a rule, the distribution of the individual quantities matters.

The key is not to be dogmatic, that is not to insist on a-priori grounds that a particular approach is the only acceptable one, regardless of the problem on is addressing. Natural scientists do not study the behaviour of gaseous clouds by aggregating the behaviour of the individual molecules that make up the cloud, but postulate behaviour at the level of the cloud. Even those economists that consider micro foundations to be a necessary feature of an acceptable macroeconomic proposition, the reductionism stops somewhere. Individual consumer are not (yet) modelled as aggregates of individual cells (or selfish genes), molecules, atoms or subatomic particles. More to the point, household behaviour is not the simple aggregation of the behaviour of a small number of individuals. A mob is not a simple

\footnotetext{
${ }^{62}$ An argument often heard in defence of behavioural rules derived from constrained optimisation (including optimising rational expectations models) is that there is only one way to be fully rational while there are infinitely many ways of being irrational (or boundedly rational). This argument is vacuous if there are no constraints on what can be included in the objective function and the constraint set (including the information set conditioning the rational expectations).

${ }^{63}$ Even when the aggregation of individual behaviours can be expressed as a relation ship between aggregate quantities only, the aggregate relationship need not look the same as (be a positive scalar multiple of) the individual relationships. An example is the Yaari-Blanchard OLG model (Blanchard [1985], Buiter [1988]).
} 
aggregation of yobs. There are aspects of the behaviour of groups and other collectives that cannot be modelled properly by aggregating the behaviour of the individuals making up the group.

At the top of Tobin's list of unfortunate theoretical developments in macroeconomic theory during his lifetime was the representative agent model. Macroeconomics, in Tobin's view, studied how a decentralised market system coordinated (and at times failed to coordinate properly) the behaviour of many heterogeneous agents. In representative agent models there is nothing to co-ordinate. There is, for instance, never any trade in equilibrium. He could conceive of few if any substantive macroeconomic problem that could be addressed adequately in a representative agent setting. His critique of the CAPM model reflects this unease with the representative agent assumption (Tobin [1983a]).

Many of Tobin's analytical writings on the effectiveness of monetary and fiscal policy discussed in Section 8 uses some version of the Neoclassical Synthesis model, the IS-LM, Aggregate Demand-Aggregate Supply model, with wage and price behaviour driven by a Phillips curve. A good retrospective on the Neoclassical Synthesis (also referred to at the New Economics during the 1960s), with a strong orientation on practical policy issues, is contained in the "Introduction" by Solow and Tobin [1988] to the volume containing the Kennedy and Reagan Economic Reports (Tobin and Weidenbaum [1988]). The private sector decision rules (consumption function, money demand function, other asset demand functions, investment function and the relations driving price, wage, employment and output determination) typically were not derived from individual optimisation and explicit aggregation.

Tobin was not at all apologetic about using ad-hoc macroeconomic tools. He agreed with the statement attributed to his friend Bob Solow that "It doesn't matter 
that something is ad-hoc, what matters is the hoc it's at". His attitude towards two alternative approaches to endow monetary policy with a real, albeit temporary effect on output and employment, short term nominal wage and/or price rigidities and limited participation models illustrates his pragmatic approach. Both approaches yield a transmission mechanism for monetary policy that makes for short-term monetary policy effectiveness, through the negative effect of a one-off increase in the level of the nominal money stock on the short nominal (and in general also the real) interest rate. Tobin embraced the approach based on ad-hoc short-term nominal wage and/or price rigidities (of the kind proposed by Taylor [1979, 1980], Fischer [1977], Calvo [1983], Buiter and Jewitt [1981] and Buiter and Miller [1985]) because it is based on a good ad-hoc assumption: the existence of nominal wage and price rigidities appeal to common sense and are supported by an impressive amount of empirical evidence, both at the macro and at the micro level (see e.g. Blinder [1991], McLaughlin [1994], Bewley [1999] and Nickell and Quintini [2003]). He did not favour the 'limited participation' model developed by Lucas [1990], Fuerst [1992] and Christiano and Eichenbaum [1992, 1995], because it is based on what he viewed as a bad ad-hoc assumption: the existence of convoluted, implausible and counterfactual constraints on the ability of households (sometimes dichotomised into shoppers and workers), firms, monetary authorities and sometimes banks, to interact and transact in the financial markets. Liquidity is a key property of financial markets, but arbitrary constraints on the timing of transactions and on who can transact with whom are unlikely to capture its essence.

Tobin was sympathetic but not uncritical towards the efforts of the New Keynesian macroeconomists to offer better microeconomic foundations for some of 
the key ad-hoc Keynesian relationships (see e.g. Mankiw and Romer [1991a, b]). ${ }^{64}$ Tobin often made the point that Keynesian models make no sense unless someone actually sets prices and wages. A competitive equilibrium model in which 'the market', that is, nobody, sets prices or wages is therefore a non-starter as Keynesian microfoundations. The monopolistic competition model of Blanchard and Kiyotaki [1987] introduced the necessary price and wage setting behaviour in a transparent and tractable manner. Monopolistic competition does not, of course, produce nominal wage or price rigidities. Here the authors appeal to menu costs. Menu costs are adhoc in two ways. First, the assumption that there is a fixed real cost associated with the change of the price of output (or of labour) in terms of the numéraire is rather arbitrary, and probably an example of bad ad-hoc in the service of spurious microfoundations. ${ }^{65}$ The same fixed cost argument should apply also to changes in financial asset prices, where it would produce seriously counterfactual results.

Second, the assumption that the numéraire is a non-produced good whose quantity can be varied costlessly and at will by the government - outside or base money - is ad-hoc, but probably good ad-hoc. While there is no theory of the selection of the numéraire in conventional unbounded rationality economics, it seems plausible that, in a boundedly rational world, the means of payment and transactions medium would be the obvious candidate for numéraire. This is made even more likely if the medium of exchange/transactions medium comes in a convenient format and benefits from legal tender status.

\footnotetext{
${ }^{64} \mathrm{He}$ recognised the PR value of attaching the label 'New' to one's product or research program - he was, after all, one of the fathers of the 'New Economics' - but would have preferred the New Keynesians to use the plain Keynesian (or, provocatively, Old Keynesian), label he applied to himself. ${ }^{65}$ Perhaps not surprising in view of Tobin's work on fixed and variable transaction costs in financial markets (Tobin [1956]), he was more tolerant of the fixed menu cost approach of e.g. Caplin and Spulber [1987], which implied the rather elegant s-S pricing policy for the individual firm, than of the assumption that the cost of changing a price is convex (e.g. quadratic) in the magnitude of the price change, which makes no sense at all (see Rotemberg [1982]).
} 
Tobin considered it an appealing feature of many New-Keynesian models, that by themselves, small menu costs and the nominal rigidities they generate would not produce first-order aggregate real effects of monetary policy (and of any other policies or events shifting aggregate demand). Some real rigidity, such as (real) efficiency wages (as in Akerlof and Yellen [1985] or Yellen [1984]) or real distortion (like monopoly or monopsony power) is required in addition to the nominal rigidity.

Not surprisingly, Tobin's view of the real business cycle (RBC) school (Kydland and Prescott [1982], Prescott [1986a,b], Plosser [1989], Mankiw [1989], Hansen and Prescott [1993]) was negative. When confronted with the early contributions of this school, Tobin could not understand why anyone would consider the addition of total factor productivity shocks to the (non-monetary) one-sector neoclassical growth model (with saving and investment determined by a representative infinite-lived consumer-entrepreneur) to be a promising candidate for explaining the business cycle in modern capitalist economies. More recent concessions to a recalcitrant reality have produced modifications to the early RBC model that move it some way towards policy relevance. Monopolistic competition, ad-hoc nominal rigidities and ad-hoc mechanisms for ensuring that rate-of-returndominated cash is held by rational, optimising agents (e.g. money in the direct utility function or cash-in-advance constraints) have made an appearance. The representative agent assumption is beginning to give way to OLG models and other tractable ways of introducing minimal irreducible heterogeneity. With the further addition of liquidity constraints for households and wedges between the cost of internal and external funds to enterprises (possibly based on optimising behaviour and acceptable primitive assumptions, such as asymmetric information and free labour), 
the New Neoclassical synthesis will be complete. It is bound to look more like Tobin's world than what the RBC school started out with. ${ }^{66}$

In his macroeconomic policy analyses, Tobin typically postulated a demand function for money that made real money balances a function of the real pecuniary rates of return on money and at least one alternative asset and of one or more scale variables such as real income, real consumption or real financial wealth. He did not consider this approach to be dominated by 'money in the direct utility function', 'money in the shopping function', 'money in the production function' or 'cash-inadvance' models, all of which provide only spurious microfoundations for money demand. ${ }^{67}$ Tobin's writings on the 'deep' micro theory of money are non-technical, yet full of insight (see e.g. Tobin [1961, 1992a]). Unfortunately there remains a yawning chasm between the deep micro theory of money, which endogenously generates the emergence of one or a few stores of value as means of payment and medium of exchange (see e.g. the search-theoretic models of Diamond [1984], Kiyotaki and Wright [1989], Aiyagari and Wallace [1992], Kehoe, Kiyotaki and Wright [1993], or Ostroy and Starr [1990] and Shubik [1990]) and anything that looks like a money demand function in a contemporary macromodel.

I learnt two key methodological lessons from Tobin. The first is that microfoundations are not synonymous with constrained optimisation - elegant and transparent as that methodology may be when used in an appropriate setting. There

\footnotetext{
${ }^{66}$ Regardless of one's view of the theoretical merits and a-priori plausibility of the RBC approach, there is a serious problem with the method of empirical verification preferred by many of its adherents. As implemented in practice, the calibration methodology of the RBC school and its offshoots sets the theory far too low a bar to pass. The standard empirical challenge is to match $N$ sample moments (typically sample means, variances and covariances) using models with at least $N$ free parameters. Obtaining theoretical conditional or unconditional moments to match these sample moments according to some rather vague metric is not a very challenging or illuminating exercise.

${ }^{67}$ The Allais-Baumol-Tobin inventory theoretic demand for money is an ad-hoc cash-in-advance model, as it assumes that all consumption purchases must be financed by running down money balances - a strict cash-in-advance constraint for consumption. It endogenises only the decision on how much cash to hold on average relative to interest-bearing assets that, ex hypothesi cannot be used to purchase consumption goods.
} 
are many alternatives - behavioural (including satisficing behaviour), psychological, socio-biological, evolutionary and more. Given the present immature state of our subject, the only wise strategy is to be tolerant of heterodoxy. It is encouraging that the 2002 Nobel Memorial Awards in Economics represent an honest admission of the uncomfortable truth that even the fundamental behavioural foundations of our subject remain an unresolved issue. ${ }^{68}$ Second, it is neither necessary nor sufficient for good macroeconomics, that aggregate relations be obtained from the explicit aggregation of individual micro-behaviour. This has value only if it produces insights and/or empirically testable results about the behaviour of the aggregates that would not have been obtained using other methods.

\section{Things Left Out}

Any attempt to do convey the depth and width of Tobin's contribution to economic science is bound to do him an injustice. I am sure there are type I and type II errors even in the topics that I have tried to cover in some depth. In addition, I have not attempted to be comprehensive in my coverage of his published work. All I can do here is list a few of the key omissions. They include Tobin's papers on development economics, written during a sabbatical in Kenya (Tobin [1973b, 1974b]; his proposal for a negative income tax (Tobin, Pechman and Mieszkowski [1967]); his

\footnotetext{
${ }^{68}$ The 2002 Nobel memorial award in Economics was shared by Daniel Kahneman and Vernon L. Smith. Both laureates are pioneers of 'experimental economics', that is, they aim to establish the behavioural foundations of economics using controlled experiments. Experimental economics, while no longer in the wilderness, remains somewhat suspect in the eyes of many members of our profession. Despite their common experimental orientation, the methodologies developed and applied by Kahneman and Smith are very different. Together with the late Amos Tversky, Kahneman has brought insights from psychology into economics and used them to develop explanations of problems and paradoxes in cognitive processes, human judgment and decision-making under uncertainty. "Prospect theory" is probably their most famous contribution (Kahneman and Tversky [1979], Tversky and Kahneman [1992]). Smith pioneered the laboratory study of market behaviour and mechanism design. Unlike Kahneman, his laboratory experiments involving strategic behaviour in auctions, in other complex markets and in non-market economic games, maintained the hypothesis of fully rational, optimising economic man (Smith [1991a, b, 2000]).
} 
later proposal for a less comprehensive but probably more nearly politically feasible version of the negative income tax (Tobin, Brainard, Shoven and Bulow [1982]); his interest in intelligent supply-side measures that would reduce the natural rate of unemployment (Baily and Tobin [1977]). Two publications from the 1960s ("Improving the Economic Status of the Negro" (Tobin [1965c]) and "Raising the Incomes of the Poor" (Tobin [1968c])) helped set the anti-poverty and inequality agenda of the Great Society years and the years immediately following. ${ }^{69}$ His proposals for structural and social policy reform are always suffused with the conviction that without sustained low unemployment, the fight against poverty and excessive inequality cannot be won. Tobin the macroeconomist, Tobin the microeconomist and Tobin the social reformer did all sing from the same hymn sheet.

Finally, a word about Tobin's Henry Simons lecture "On Limiting the Domain of Inequality" (Tobin [1970b]). It stands out not because of its characteristic clarity of style, which one expects to find in Tobin's writings, but because there is nothing quite like it in Tobin's published work. It ranges across issues as diverse as the merits of a free market in votes, the draft and selective service, the right to bear children (and the merits of voucher systems for distributing a limited number of 'birth rights'), education vouchers, the fair and efficient provision of medical care, foodstamps and housing. In this paper Tobin is willing to consider, and provides a lucid analysis of, a range of very radical reform proposals. While he does not engage in overt advocacy of any particular proposal, it definitely appears as if, in some of the welfare, health, education and social reform areas, Tobin and Milton Friedman may have been less far apart than they were on macroeconomic issues. Indeed, like Tobin, Friedman was an

\footnotetext{
${ }^{69}$ The proposals made by Tobin are, by American standards, radical but not revolutionary. Indeed the first sentence of Tobin [1965c] is: "I start from the presumption that the integration of Negroes into the American society and economy can be accomplished within existing political and economic institutions".
} 
advocate of the negative income tax, an unequivocal supporter of free trade in goods and services (Tobin [1991]). and a proponent of a floating exchange rate.

\section{Conclusion}

The two economists Tobin admired most were John Maynard Keynes and Irving Fisher. This is not surprising, as he combined in himself the best of both. Tobin had Fisher's analytical skills, insistence on clarity and rigour and attention to relevant detail. ${ }^{70} \mathrm{He}$ had Keynes's talent for identifying the key economic issues of the time and for cutting through irrelevant detail to address the core analytical and policy issues. Economics was never an end in itself, but always a means to the end of contributing to be better society - a toolkit. But Tobin respected the toolkit and insisted that passion and engagement could never be a substitute for clarity, rigour and intellectual honesty.

Each of the nine or ten aspects of his work discussed in this paper is an impressive, masterful contribution to economic science. The sum of the parts is awesome indeed. But the man was so much more than the sum of these parts. We mourn what we lost when Jim Tobin died, yet we are fortunate to be the heirs to such a rich legacy.

\footnotetext{
${ }^{70}$ Some critics of Tobin have argued that he did not wield Occam's razor with sufficient determination when it came to presenting his ideas. Even though I have voiced a muted version of this criticism in my discussion of his "Dynamic Aggregative Model", I believe it to be too harsh. The "when in doubt, leave it out' approach carries risks, and nobody has identified these risks better than Tobin in his discussion of Friedman's A Theory of the Consumption Function (Friedman [1957]). Tobin's review ends with the (rhetorical) question: "It is certainly better to be simple than complicated. But is it better to be simple than right?" Tobin [1958c, 1975, p. 124]
} 


\section{References}

Akerlof, George A. and Janet L. Yellen [1985], "A Near-Rational Model of the Business Cycle, with Wage and Price Inertia", Quarterly Journal of Economics, 100, Supplement, pp. 823-38.

Allais, Maurice [1947], Economie et Intérêt, Paris, Imprimerie Nationale.

Ando, Albert and Franco Modigliani [1963], "The life cycle hypothesis of saving", American Economic Review, 53, March, pp. 55-84.

Auerbach, Alan J. and Laurence J. Kotlikoff [1987], Dynamic Fiscal Policy, Cambridge, Cambridge University Press.

Aiyagari, Rao and Neil Wallace [1992], "Fiat Money in the Kiyotaki-Wright Model", Economic Theory 2, 447-464.

Backus, David, William C. Brainard, Gary Smith and James Tobin [1980], "A Model of U.S. Financial and Nonfinancial Economic Behavior", Journal of Money, Credit and Banking, 12(2), May, pp. 259-293.

Baily, Martin Neil and JamesTobin [1977], "Macroeconomic Effects of Selective Public Employment and Wage Subsidies", Brookings Papers on Economic Activity, 2, pp. 511-541.

Barberis, Nicholas and Richard Thaler [2002], "A Survey of Behavioral Finance", NBER Working Paper No. W9222, September.

Barro, Robert J, [1974], “Are Government Bonds Net Wealth”, Journal of Political Economy, 82, November/December, pp. 1095-1117.

Barro, Robert J. [1976], "Rational Expectations and the Role of Monetary Policy", Journal of Monetary Economics, 2, January, pp. 1-32.

Baumol, William J. [1952], “The Transactions Demand for Cash: an Inventory Theoretic Approach", Quarterly Journal of Economics, 56, November, pp. 545-56.

Baumol, William J. and James Tobin [1989], "The Optimal Cash Balance Proposition: Maurice Allais's Priority", Journal of Economic Literature, 27, September, pp. 1160-1162.

Bernanke, Ben S. and Alan S. Blinder [1988], "Credit, Money, and Aggregate Demand," American Economic Review, Vol. 78 (2) pp. 435-39.

Bernanke, Ben S and Alan S. Blinder [1992], "The Federal Funds Rate and the Channels of Monetary Transmission," American Economic Review, Vol. 82 (4) pp. 901-21.

Bernanke, Ben and Mark Gertler [1989]. "Agency Costs, Net Worth, and Business Fluctuations," American Economic Review, Vol. 79 (1) pp. 14-31. 
Bernanke, Ben S. and Mark Gertler [1995], "Inside the Black Box: The Credit Channel of Monetary Policy Transmission," Journal of Economic Perspectives, Vol. 9 (4) pp. 27-48.

Bewley, T.F. [1999], Why Wages Don't Fall During a Recession, Harvard University Press, Cambridge MA.

BIS Review [1997], "Address by the Governor of the South African Reserve Bank", 108/1997.

Blanchard, Olivier [1985], "Debt, deficits and finite horizons", Journal of Political Economy, 93, April, pp. 223-47.

Blanchard, Olivier and Nobuhiro Kiyotaki [1987], "Monopolistic competition and the effects of aggregate demand", American Economic Review 77, pp. 647-666

Blinder, Alan S. [1991] "Why are Prices Sticky? Preliminary Results from an Interview Study," AER_Papers and Proceedings.

Blinder, Alan S. and Robert M. Solow [1973], "Does Fiscal Policy Matter", Journal of Public Economics, 2, pp. 319-37.

Borch, Karl and Martin Feldstein [1969], "Mean-Variance Analysis in the Theory of Liquidity Preference and Portfolio Selection", Review of Economic Studies, 36(1), January, pp. 1-12.

Brainard, William C. [1964], "Financial Intermediaries and a Theory of Monetary Control”, Yale Economic Essays, 4, No 1. Fall, pp. 431-82.

Brainard, William C. and James Tobin [1968], "Pitfalls in Financial Model Building", American Economic Review (Papers and Proceedings), 58, May, pp. 99-122.

Brainard, William C., John B. Shoven and L Weiss [1981], "The financial valuation of the return to capital", Brookings Papers on Economic Activity, 2, pp. 453-502.

Bray, Margaret 1982], "Leaning, Estimation, and the Stability of Rational Expectations Equilibria", Journal of Economic Theory, 26. pp. 318-339.

Brunner, Karl and Allan H. Meltzer [1972], "Money, Debt, and Economic Activity", Journal of Political Economy, Vol. 80, No. 5, pp. 951-977

Bryant, J.,"A Simple Rational Expectation Keynes-Type Model [1983]," Quarterly Journal of Economics, 97, 525-529.

Buiter, Willem H. [1981], "The superiority of contingent rules over fixed rules in models with rational expectations", Economic Journal, 91, September, pp. 647-70.

Buiter, Willem H. [1988], "Death, Birth, Productivity Growth and Debt Neutrality", Economic Journal, 98, June, pp. 279-93. 
Buiter, Willem H. [2002] "The Fiscal Theory of the Price Level: A Critique", Economic Journal, Vol 112, July, pp. 459-480.

Buiter, Willem H. and Ian Jewitt [1981], "Staggered wage setting with real wage relativities: variations on a theme of Taylor", Manchester School, 49, pp. 211-28, reprinted in Willem H. Buiter, Macroeconomic Theory and Stabilization Policy, Manchester University Press, Manchester University Press, 1989 and University of Michigan Press, 1990, pp. 183-199.

Buiter, Willem H. and Marcus H. Miller [1985], "Costs and Benefits of an AntiInflationary Policy: Questions and Issues," in Inflation and Unemployment: Theory, Experience and Policy-Making, V.E. Argy and J.W. Nevile (eds.), George Allen \& Unwin, London, 1985, 11-38, reprinted in Willem H. Buiter, Macroeconomic Theory and Stabilization Policy, and University of Michigan Press, 1990.

Calvo, Guillermo [1983], "Staggered Contracts in a Utility-Maximizing Framework," Journal of Monetary Economics, September.

Canada, House of Commons. [1983]. Standing Committee on Finance, Trade and Economic Affairs. Minutes of Proceedings and Evidence, No. 134, 28 March, p. 12.

Caplin, Andrew S. and Daniel F. Spulber [1987], "Menu Costs and the Neutrality of Money", Quarterly Journal of Economics, 102, November, pp. 703-725.

Caroll, Lewis [1871], Through the Looking Glass and What Alice Found There. Macmillan, London.

Christ, Carl F. [1968], "A simple macroeconomic model with a government budget constraint", Journal of Political Economy, 76, pp. 53-67.

Christiano, L J and Eichenbaum, M [1992], 'Liquidity effects and the monetary transmission mechanism', American Economic Review, pages 346-53.

Christiano, L J and Eichenbaum, M [1995], 'Liquidity effects, monetary policy and the business cycle', Journal of Money, Credit and Banking, pages 1,113-36.

Cochrane, John H. [1998], "A Frictionless model of U.S. Inflation", NBER Macroeconomics Annual, April.

Cooper, R. and A. John [1988], "Coordinating Coordination Failures in Keynesian Models," Quarterly Journal of Economics, 103, 441-63.

Cox, J.D., J.E. Ingersoll and S.A. Ross [1985], "An Intertemporal General Equilibrium Model of Asset Prices", Econometrica, 53, March, pp. 385-408.

Crotty, James R. [1990], "Owner-Manager Conflict and Financial Theories of Investment Instability: A Critical Assessment", Journal of Post Keynesian Economics, Summer, 12(4), pp. 519-42. 
Dawid, H. [1996], “Adaptive Learning by Genetic Algorithms: Analytical Results and Applications to Economic Models”. Springer-Verlag, Berlin.

Debreu, Gerard [1974], "Excess demand functions," Journal of Mathematical Economics, 1, pp. 15-21.

Diamond, Peter A. [1965], "National Debt in a Neoclassical Growth Model", American Economic Review, 55, December, pp. 881-894.

Diamond, Peter [1984], “Money in Search Equilibrium”, Econometrica 52, 1-20.

Dolde, Walter and James Tobin [1983], "Mandatory Retirement Saving and Capital Formation", in Franco Modigliani and Richard Hemming eds. The Determinants of National Saving and Wealth, London, Macmillan Press.

Duesenberry, James S. [1949], Income, Saving and the Theory of Consumer Behavior, Cambridge Mass. Harvard University Press.

Eckstein, Otto [1981], Core Inflation, Prentice-Hall, Englewood Cliffs, NJ.

Ellison, Glenn and Drew Fudenberg [1993], "Rules of Thumb for Social Learning", Journal of Political Economy, 104(4), August, pp. 612-43.

Elmendorf Douglas W., and Gregory N. Mankiw [1999], "Government Debt", Handbook of Macroeconomics, Vol. 1, Taylor, J.B. and M. Woodford, eds. ,Elsevier Science, B.V., 1999, pp. 1615-1699.

Epstein, Larry G. and Stanley E. Zin [1991], "Substitution, Risk Aversion, and the Temporal Behavior of Consumption and Asset Returns: An Empirical Analysis, Journal of Political Economy, 99 (2), April, pp. 263-286.

Evans, G.W. [1983], "The Stability of Rational Expectations in Macroeconomic Models", in Individual Forecasting and Aggregate Outcomes, 'Rational Expectations' Re-examined”, R. Frydman and E.E. Phelps, eds. , pp. 67-94, Cambridge University Press, Cambridge.

Evans, George W. an Seppo Honkapohja [2001], Learning and Expectations in Macroeconomics, Princeton University Press, Princeton.

Fischer, Stanley [1977], “'Long-Term Contracts, Rational Expectations, and the Optimal Money Supply Rule.” Journal of Political Economy, 85, February, pp. 191205.

Fischer, Stanley [1979], "Capital Accumulation on the Transition Path in a Monetary Optimizing Model," Econometrica, November, 1433-40.

Fisher, Irving [1926], “A Statistical Relationship Between Unemployment and Price Changes", International Labour Review, June, pp. 785-92. 
Fisher, Irving [1930], The Theory of Interest, New York, Macmillan.

Friedman, Benjamin M. [1976], "Public Pension Funding and U.S. Capital Formation: A Medium-Run View", in Funding Pensions: Issues and Implications for Financial Markets, Federal Reserve Bank of Boston, Proceedings of a Conference, October.

Friedman, Benjamin M. [1978], "Crowding Out or Crowding In? The Economics Consequences of Financing Government Deficits", Brookings Papers on Economic Activity, 3.

Friedman, Milton, ed. [1956], Studies in Quantity Theory of Money, Chicago, University of Chicago Press.

Friedman, Milton [1957], A Theory of the Consumption Function, National Bureau of Economic Research Series, General Series No. 63, Princeton University Press.

Friedman, Milton [1959], "The Demand for Money: Some theoretical and empirical results", Journal of Political Economy,

Friedman, Milton [1968], "The role of monetary policy", American Economic Review, 58, March, pp. 1-17.

Friedman, Milton [1969], The Optimum Quantity of Money and other Essays, Aldine Publishing Company, Chicago.

Friedman, Milton [1970], “Comment on Tobin", Quarterly Journal of Economics, May.

Friedman, Milton [1971] "A Monetary Theory of Nominal Income," Journal of Political Economy, (March/April).

Friedman, Milton [1972], "Comments on the critics", Journal of Political Economy, Sept. Oct.

Friedman, Milton and Anna Schwartz [1963], A Monetary History of the United States 1879-1960, Princeton University Press, Princeton.

Fuerst, T. S. [1992], "Liquidity, loanable funds, and real activity". Journal of Monetary Economics 29, pp. 3-24.

Geanakoplos, John, O. Mitchell and S. Zeldes [1998], "Would a Privatized Social Security System Really Pay a Higher Rate of Return?" in Framing the Social Security Debate. Values, Economics, and Politics, R.D. Arnold, M. Graetz and A. Munnell, eds., National Academy of Social Insurance, (1998), pp. 137-157

Geanakoplos, John, O. Mitchell and S. Zeldes [2002], "Social Security Money's Worth," in Prospects for Social Security Reform, O. Mitchell, R. Myers and H. Young, eds., Pension Research Council, The Wharton School, University of Pennsylvania Press, Philadelphia, 1999, pp. 79-151. 
Goodhart, C.A.E. [1984], Monetary Theory and Practice: The U.K. Experience, Macmillan, London, 1984.

Granger, C.W.J. [1980], "Testing for Causality: a Personal Viewpoint”, Journal of Economic Dynamics and Control, 2, pp. 329-52.

Grossman, Herschel I. [1975], "Tobin on Macroeconomics: A Review Article", Journal of Political Economy, 83(4), August, pp. 829-847.

Grossman, Herschel I. [1982], Asset Accumulation and Economic Activity: Reflections on Contemporary Macroeconomic Theory, by James Tobin, Journal of Monetary Economics, 10, July, pp. 134-138.

Hall, Robert E. [1988], "Intertemporal Substitution in Consumption," Journal of Political Economy, Vol. 96, No.2, pp. 339-357.

Hansen, Gary D. and Edward C. Prescott (1993): "Did Technology Shocks Cause the 1990-91 Recession?" American Economic Review Papers and Proceedings, 83(2):280-86.

Hayashi, Fumio [1982], “Tobin's Marginal q and Average q: A Neoclassical Interpretation", Econometrica 50(1), January, pp. 213-24.

Heckman, James J.[1979], "Sample Selection Bias as a Specification Error." Econometrica, 47(1), pp. 153-162.

Houthakker, H.S. and James Tobin [1952], "Estimates of the Free Demand for Rationed Foodstuffs", Economic Journal, 62, March, pp. 103-118.

Iwai, Katsuhito [1981], Disequilibrium Dynamics - A Theoretical Analysis of Inflation and Unemployment, Cowles Foundation Monograph 27, New Haven: Yale University Press.

Kahneman, D. and Tversky, A. [1979]. "Prospect theory: An analysis of decision under risk" Econometrica, 47, 263-291.

Kashyap, Anil K, Jeremy C. Stein and David W. Wilcox [1993], "Monetary Policy and Credit Conditions: Evidence from the Composition of External Finance," American Economic Review, Vol. 83 (1) pp. 78-98.

Kehoe, Timothy J., Nobuhiro Kiyotaki and Randall Wright [1993], "More on Money as a Medium of Exchange", Economic Theory 3, 297-314.

Keynes, John M. [1936], The General Theory of Employment, Interest, and Money, Macmillan, London.

Kiyotaki, Nobuhiro and Randall Wright [1989], "On Money as a Medium of Exchange," Journal of Political Economy, Vol. 97 (4) pp. 927-54. 
Kydland, Finn E., and Edward C. Prescott [1982], "Time to Build and Aggregate Fluctuations." Econometrica, 50:1345-1370

Lintner, John H. [1965], "The Evaluation of Risk Assets and the Selection of Risky Investments in Stock Portfolios and Capital Budgets", Review of Economics and Statistics, 47, February, pp. 13-37.

Lucas, Robert E. [1972], "Expectations and the Neutrality of Money", Journal of Economic Theory 4, April, pp. 103-124.

Lucas, Robert E. [1976], "Econometric Policy Evaluation: A Critique", in Lucas [1981a], in Karl Brunner and Allan H. Meltzer eds. The Phillips Curve and Labour Markets, pp. 19-46, Vol. 1 of Carnegie-Rochester Conference Series on Public Policy, Amsterdam North Holland, reprinted in Robert E. Lucas, Studies in Business Cycle Theory, Cambridge: MIT Press, pp.104-30.

Lucas, R.E. Jr [1980], "Methods and Problems in Business Cycle Theory”, Journal of Money, Credit and Banking 12, November, Part 2, reprinted in Lucas [1981a].

Lucas, R.E. Jr. [1981a], Studies in Business-Cycle Theory, Basil Blackwell, Oxford.

Lucas, R.E. Jr. [1981b], "Tobin and Monetarism: A Review Article", Journal of Economic Literature, XIX, June, pp. 558-567.

Lucas, R E Jr [1990], "Liquidity and interest rates", Journal of Economic Theory, pages 237-64.

Lucas, Robert E. and Leonard A. Rapping [1969], "Real Wages, Employment, and Inflation”, Journal of Political Economy, 77, September/October, pp. 721-754.

Lucas, Robert E. and Thomas J. Sargent [1978], “After Keynesian Macroeconomics”, in Federal Reserve Bank of Boston, After the Phillips Curve: Persistence of High Inflation and High Unemployment, Conference Series No. 19, reprinted in Lucas [1981a].

Magnus, Jan R. and Mary S. Morgan [1999], Methodology and Tacit Knowledge: Two Experiments in Econometrics, John Wiley \& Sons: Chichester/New York.

Mankiw, N. Gregory [1989]: "Real Business Cycles: A New Keynesian Perspective." Journal of Economic Perspectives, 3, pp. 79-90.

Mankiw, Gregory N. and David Romer [1991a], New Keynesian Economics, Volume 1, Imperfect Competition and Sticky Prices, Cambridge MA, The MIT Press.

Mankiw, Gregory N. and David Romer [1991b], New Keynesian Economics, Volume 2, Coordination Failures and Real Rigidities, Cambridge MA, The MIT Press.

Mankiw, Gregory N. and Matthew D. Shapiro [1986], "Risk and Return: Consumption Beta versus Market Beta", Review of Economics and Statistics, 68, pp. $452-459$. 
Mantel R. [1974], "On the characterization of aggregate excess demand," Journal of Economic Theory, 7, pp. 348-353

Marcet, A. and T.J. Sargent [1989], "Convergence of Least-Squares Learning in Environments with Hidden State Variables and Private Information", Journal of Political Economy, 97, pp. 1306-1322.

Marimon, R. [1997], "Learning from Learning in Economics", in Advances in Economics and Econometrics: Theory and Applications, D. Kreps and K. Wallis eds., pp. 278-315, Cambridge University Press, Cambridge.

Markowitz, H. [1952], "Portfolio Selection”, Journal of Finance, 7, March, pp. 77-91.

Markowitz, H. [1959], Portfolio Section, New York, Wiley.

Markowitz, H., Portfolio Selection: Efficient Diversification of Investments (Yale University Press 1970.

McCallum, Bennett T. [1979], "The current state of the policy-ineffectiveness debate", American Economic Review, Papers and Proceedings, 69(2).

McCallum, Bennett T. [1988], "Robustness Properties of a Rule for Monetary Policy," Carnegie-Rochester Conference Series on Public Policy 29 (Autumn), pp. 173-203.

McCallum, Bennett t. [1999], "Issues in the Design of Monetary Policy Rules," in Handbook of Macroeconomics, eds. John B. Taylor and Michael Woodford, Amsterdam: North-Holland Pub. Co.

McLaughlin K. J. [1994], "Rigid Wages", Journal of Monetary Economics, 34(3), pp. 384-414.

Merton, Robert C. [1969], "Lifetime Portfolio Selection Under Uncertainty: The Continuous-Time Case", Review of Economics and Statistics, 51, August, pp. 247-57.

Modigliani, Franco and Richard Brumberg [1954], "Utility Analysis and the Consumption Function: An Interpretation of Cross Section Data," in Post-Keynesian Economics, K. Kurihara ed., New Brunswick, Rutgers University Press, pp. 388-436.

Modigliani, Franco and Richard Cohn [1979], Inflation, Rational Valuation and the Market", Financial Analysts Journal, 35, pp. 24-44.

Mossin, J. [1966], "Equilibrium in a Capital Asset Market," Econometrica 34, No. 4 October, pp. 768-783.

Mossin, J. [1968], “Optimal Multiperiod Portfolio Policies,” Journal of Business, 4, No. 2, April, pp. 215-229. 
Nelson, Richard R. and Sidney G. Winter [1982] An Evolutionary Theory of Economic Change, Harvard University Press, Cambridge, Mass.

Nickell, S. and G. Quintini [2003], "Nominal wage rigidity and the rate of inflation", Discussion Paper No. 489, Centre for Economic Performance, London School of Economics, September 2001, revised November 2002, forthcoming Economic Journal.

Nordhaus, William and James Tobin [1973a], "Is Growth Obsolete", in Milton Moss, ed., The Measurement of Economic and Social Performance, Studies in Income and Wealth, Vol. 38, National Bureau of Economic Research.

Nordhaus, William and James Tobin [1973b], "Denison and Usher; Reply by Nordhaus and Tobin", The Measurement of Economic and Social Performance, ed. Milton Moss, New York: National Bureau of Economic Research, Cambridge University Press, New York and London, 1973, pp. 554-564.

Okun, Arthur M. [1981], Prices and Quantities: A Macroeconomic Analysis, The Brookings Institution, Washington D.C.

Ostroy, Joseph M. and Ross M. Starr [1990], "The Transaction Role of Money, in Handbook of Monetary Economics, edited by B. Friedman and F. Hahn, Amsterdam: North-Holland.

Phelps, Edmund S. [1972], Inflation Policy and Unemployment Theory, New York, Norton.

Phelps, Edmund S. et. al. [1970], Microeconomic Foundations of Employment and Inflation Theory, W.W. Norton and Co. Inc.

Pissarides, Christopher A. [2000], Equilibrium Unemployment Theory, Second Edition, Cambridge, MA: MIT Press.

Plosser, Charles [1989]: "Understanding Real Business Cycles." Journal of Economic Perspectives, 3:51-78.

Prescott, Edward C. [1986]: "Theory Ahead of Business Cycle Measurement." Federal Reserve Bank of Minneapolis Quarterly Review, 10:23-27 (Fall). Reprinted in Preston J. Miller, ed., The Rational Expectations Revolution. Readings from the Front Line. Cambridge, MA: MIT Press (1994).

Prescott, Edward C. (1986): "Response to a Skeptic." Federal Reserve Bank of Minneapolis Quarterly Review,10: (Fall). Reprinted in Preston J. Miller, ed., The Rational Expectations Revolution. Readings from the Front Line. Cambridge, MA: MIT Press (1994).

Robinson, Joan [1956], The Accumulation of Capital, Macmillan, London.

Rotemberg, J. [1982], "Sticky Prices in the United States", Journal of Political Economy, 90, pp. 1187-1211. 
Samuelson, Paul A. [1958], "An Exact Consumption-Loan Model of Interest with or without the Social Contrivance of Money", Journal of Political Economy 66, pp. 467482.

Samuelson, Paul A. [1969], Lifetime Portfolio Selection by Dynamic Stochastic Programming." Review of Economics and Statistics, 51, pp. 239-246.

Sargent, T.J. [1987], Dynamic Macroeconomic Theory, Harvard University Press, Cambridge Mass.

Sargent, T. J. [1993], Bounded Rationality in Macroeconomics, Oxford University Press, Oxford.

Sargent, T.J. and N. Wallace [1975], "Rational expectations, the optimal monetary instrument and the optimal money supply rule", Journal of Political Economy, 83, April, pp. 241-54.

Sargent T. J. and N. Wallace [1981], "Some Unpleasant Monetarist Arithmetic", Federal Reserve Bank of Minneapolis Quarterly Review, 5, Fall.

Selgin, G. [2003], “Adaptive Learning and the Transition to Fiat Money”, Economic Journal, 113(484), January, pp. 147-165.

Sharpe, W.F. [1964], "Capital Asset Prices: A Theory of Market Equilibrium under Conditions of Risk", Journal of Finance, 19, September, pp. 425-442.

Shiller, Robert J. [1979], "The Volatility of Long-Term Interest Rates and Expectations Models of the Term Structure", Journal of Political Economy, 87, pp. 1190-219.

Shiller, Robert J. [1981], "Do Stock Prices Move Too Much to be Justified by Subsequent Changes in Dividends?”, American Economic Review, 71, pp. 421-36.

Shiller, Robert J. [1999], "Human Behavior and the Efficiency of Financial Markets," for Handbook of Macroeconomics, Vol. 1, pp.1305-40.

Shiller, Robert J. [2000], Irrational Exuberance, Princeton University Press, Princeton NJ.

Shiller, Robert J. [2003], The New Financial Order: Risk in the 21st Century, Princeton University Press, Princeton NJ.

Shleifer, Andrei [2000] Clarendon Lectures: Inefficient Markets, Oxford University Press.

Shubik, Martin [1990], "A Game Theoretic Approach to the Theory of Money and Financial Institutions", in Handbook of Monetary Economics, edited by B. Friedman and F.Hahn, Amsterdam: North-Holland. 
Sidrauski, M. [1967], "Inflation and Economic Growth", Journal of Political Economy, Vol. 75, No. 4, December, pp. 796-810.

Sims, C. A. [1994], 'A Simple Model for Study of the Determination of the Price Level and the Interaction of Monetary and Fiscal Policy', Economic Theory, 4, pp. 381-399.

Smith Vernon L. [1991a], "Rational choice - the contrast between economics and psychology", Journal of Political Economy 99, pp. 877-897.

Smith Vernon L. [1991b], Papers in Experimental Economics, Cambridge University Press, Cambridge.

Smith, Vernon L. [2000], Bargaining and Market Behavior : Essays in Experimental Economics, Cambridge University Press, Cambridge.

Solow, Robert M. [1956], "A contribution to the Theory of Economic Growth", Quarterly Journal of Economics, 70, February, pp. 65-94.

Solow, Robert M., James Tobin, C.C. von Weizsäcker and M. Yaari [1966], "Neoclassical Growth with Fixed Factor Proportions", Review of Economics Studies, April, pp. 79-115.

Solow, Robert M. and James Tobin [1988], "Introduction", in Tobin and Weidenbaum [1988], pp. 3-16.

Sonnenschein, Hugo [1973], "Do Walras' identity and continuity characterize the class of community excess demand functions?," Journal of Economic Theory, 6, pp. 345-354.

Sonnenschein, Hugo [1974], "Market excess demand functions," Econometrica, 40, pp. 549-563.

Stokey, Nancy L. and Robert E. Lucas Jr. with Edward C. Prescott [1989], Recursive Methods in Economic Dynamics, Harvard University Press, Cambridge Mass.

Summers, Lawrence H. [1981], "Taxation and corporate investment: a q-theoretic approach", Brookings Papers on Economic Activity, 1, pp. 67-140.

Swan, T.W. [1956], "Economic Growth and Capital Accumulation", Economic Record, 32, November, pp. 334-361.

Taylor, John B [1979], "Staggered Wage Setting in a Macro Model", American Economic Review, Vol. 69, No. 2, pp. 108-113.

Taylor, John B. [1980], “Aggregate Dynamics and Staggered Contracts”, Journal of Political Economy, Vol. 88, No.1, pp. 1-23.

Taylor, John B. [1993], "Discretion Versus Policy Rules in Practice," CarnegieRochester Series on Public Policy, North-Holland, 39, pp. 195-214. 
Taylor, John B. ed. [1999], Monetary Policy Rules, Chicago, University of Chicago Press.

Tobin, James [1941], “A note on the money wage problem", Quarterly Journal of Economics, May, pp. 508-516.

Tobin, James [1947a], A Theoretical and Statistical Analysis of Consumer Saving, Harvard University Ph.D. Thesis.

Tobin, James [1947b], "Liquidity Preference and Monetary Policy", Review of Economics and Statistics, 29, May, pp. 124-31.

Tobin, James [1948], “A Rejoinder to Dr. Wharburton", Review of Economics and Statistics, 30, November, pp.314-17.

Tobin, James [1950], "A Statistical Demand Function for Food in the U.S.A.", Journal of the Royal Statistical Society, 113, Series A, Part II, pp. 113-41; also in Magnus and Morgan [1999].

Tobin, James [1951], "Relative Income, Absolute Income and Savings," in Model, Trade and Economic Growth: Essays in Honor of J. H. Williams, (Macmillan).

Tobin, James [1952a], "Asset Holdings and Spending Decisions", American Economic Review, Papers and Proceedings, 42, May, pp. 109-123.

Tobin, James [1952b], "A Survey of the Theory of Rationing", Econometrica, 20, October, pp. 521-53.

Tobin, James [1955a], "Multiple Probit Regression of Dichotomous Economic Variables", Cowles Foundation Discussion Paper No. 1, reprinted in James Tobin [1975a], Essays in Economics, Volume 2: Consumption and Econometrics, North Holland, Amsterdam, pp. 447-466.

Tobin, James [1955b], "A Dynamic Aggregative Model”, Journal of Political Economy, 63, April, pp. 103-15.

Tobin, James [1956], "The Interest-Elasticity of Transactions Demand for Cash", Review of Economics and Statistics, 38, August, pp. 241-47.

Tobin, James [1957], "Consumer Debt and Spending: Some Evidence From Analysis of a Survey", in National Bureau of Economic Research, Consumer Installment Credit, Part II, Vol 1, Washington: U.S. Government Printing Office.

Tobin, James [1958a], "Estimation of Relationships for Limited Dependent Variables", Econometrica, 26, January, pp. 24-36.

Tobin, James [1958b], "Liquidity Preference as Behaviour Towards Risk", Review of Economic Studies, 25, No. 67, pp. 65-86. 
Tobin, James [1958c], "Milton Friedman's Theory of the Consumption Function", in Lincoln H. Clark ed. Consumer Behavior, New York, Harper, reprinted in Tobin [1975].

Tobin, James [1959], "On the Predictive Value of Consumer Intentions and Attitudes", Review of Economics and Statistics, 41, February, pp. 1-11.

Tobin, James [1961], "Money, Capital, and Other Stores of Value", American Economic Review, Papers and Proceedings, 51, May, pp. 26-37.

Tobin, James [1963a], "An Essay on the Principles of Debt Management", in Fiscal and Debt Management Policies, Englewood Cliffs, N.J.; Prentice Hall, pp. 143-218.

Tobin, James [1963b], "Commercial Banks as Creators of "Money"”, in Dean Carson ed. Banking and Monetary Studies, pp. 408-19, Homewood, Ill.: Richard D. Irwin.

Tobin, James [1964], "Economic Growth and An Objective of Government Policy", American Economic Review, Papers and Proceedings, 54, May, pp. 1-20.

Tobin, James [1965a], “Money and Economic Growth”, Econometrica, 33(4), pp. 671-84.

Tobin, James [1965b], "The Monetary Interpretation of History (A Review Article)", American Economic Review, 55( 3), June, pp. 464-85.

Tobin, James [1965c], "On Improving the Economic Status of the Negro", Deadalus, 94(4), Fall, pp. 878-898.

Tobin, James [1967a], "Life Cycle Saving and Balanced Growth", in Wm. Fellner (ed.), Ten Economic Studies in the Tradition of Irving Fisher, pp. 231-56, New York: Wiley.

Tobin, James [1967b], “The Cruel Dilemma”, in Price Issues in Theory, Practice and Policy, Almarin Phillips ed. University of Pennsylvania Press, reprinted in James Tobin, Essays in Economics, Volume 2, Consumption and Econometrics, pp. 3-10, MIT Press, 1987, Cambridge Mass.

Tobin, James [1968a], "Phillips Curve Algebra", in James Tobin, Essays in Economics, Volume 2, Consumption and Econometrics, pp. 11-15, MIT Press, 1987, Cambridge Mass; adapted from Tobin's "Discussion" of papers at a Symposium on Inflation: Its Causes, Consequences and Control, 1968, Stephen W. Rousseas ed. pp. 48-54 and from Tobin's "Comment", Brookings Papers on Economic Activity, 1971:2, pp. 512-14.

Tobin, James [1968b], "Notes on Optimal Monetary Growth", Journal of Political Economy, 76, July-August, pp. 833-59.

Tobin, James [1968c], "Raising the Incomes of the Poor", in Agenda for the Nation, ed. K. Gordon, pp. 77-116, the Brookings Institution, Washington D.C. 
Tobin, James [1968d], “The Consumption Function”, in International Encyclopaedia of the Social Sciences, Vol III, pp. 358-68, reprinted in Tobin [1975].

Tobin, James [1969a], "Comment on: "Mean-Variance Analysis in the Theory of Liquidity Preference and Portfolio Selection"', by Borch, Karl and Martin Feldstein, Review of Economic Studies 36(1), January, pp. 13-14.

Tobin, James [1969b], "A general Equilibrium Approach to Monetary Theory", Journal of Money, Credit and Banking, 1, February, pp. 15-29.

Tobin, James [1970a], "Money and Income: Post Hoc Ergo Propter Hoc", Quarterly Journal of Economics, 84, May, pp. 301-17.

Tobin, James [1970b], "On limiting the domain of inequality", The Journal of Law and Economics, 13(2), October, pp. 263-277.

Tobin, James [1970c], "Rejoinder”, Quarterly Journal of Economics, May.

Tobin, James [1970d], "Deposit Interest Ceilings as a Monetary Control", Journal of Money, Credit and Banking, 2, February, pp. 4-14.

Tobin, James [1971], Essays in Economics, Volume 1, Macroeconomics, Chicago: Markham Publishing Company.

Tobin, James [1972a], "Inflation and Unemployment", American Economic Review, March, pp. 1-18.

Tobin, James [1972b], “Friedman's Theoretical Framework”, Journal of Political Economy, September/October.

Tobin, James [1972c], "Wealth, Liquidity and the Propensity to Consume", in Human Behavior in Economic Affairs; Essays in Honor of George Katona, eds., B. Strumpel, James N. Morgan, and Ernest Zahn, Elsevier Scientific Publishing Co., Amsterdam, pp. 36-56

Tobin, James [1973a], "The Wage-Price Mechanism”, S. Weiner ed. The Econometrics of Price Determination Conference, Board of Governors, Federal Reserve System, reprinted in James Tobin, Essays in Economics, Volume 2, Consumption and Econometrics, pp. 17-32, MIT Press, 1987, Cambridge Mass.

Tobin, James [1973b], "Notes on the Economic Theory of Expulsion and Expropriation", Journal of Development Economics, 1, pp. 7-18.

Tobin, James [1974a], The New Economics One Decade Older, Princeton University Press.

Tobin, James [1974b], "Technological Development and Employment", Eastern Africa Economic Review, 6(1), June, pp. 1-26. 
Tobin, James [1974c], "What is Permanent Endowment Income?" American Economic Review, 64(2), pp. 427-432.

Tobin, James [1975a], Essays in Economics, Volume 2: Consumption and Econometrics, North Holland, Amsterdam.

Tobin, James [1975b], "Keynesian Models of Recession and Depression", American Economic Review, Papers and Proceedings 65(2), pp. 195-202.

Tobin, James [1976], "Discussion: of "Public Pension Funding and U.S. Capital Formation: A Medium-Run View", by Benjamin M Friedman," in Funding Pensions: Issues and Implications for Financial Markets, Federal Reserve Bank of Boston, Proceedings of a Conference, Oct., pp. 206-12.

Tobin, James [1978], “A Proposal for International Monetary Reform”, Eastern Economic Journal, 4, pp. 153-9.

Tobin, James [1979], "Deficit Spending and Crowding Out in Shorter and Longer Runs", in Harry I. Greenfield et. al. eds. Theory for Economic Efficiency: Essays in Honor of Abba P. Lerner, pp. 217-236, Cambridge Mass. MIT Press.

Tobin, James [1980], Asset Accumulation and Economic Activity, Basil Blackwell, Oxford.

Tobin, James [1981], "Reflections Inspired by Proposed Constitutional Restrictions on Fiscal Policy", in Kenneth D. Boyer and William G. Shepherd eds. Economic Regulation: Essays in Honor of James R. Nelson, East Lansing, MI: Bureau of Research, Michigan State University Press.

Tobin, James [1982a], "Money and Finance in the Macroeconomic Process", Journal of Money, Credit and Banking, 14(2), pp. 171-204.

Tobin, James [1982b], “Against the Balanced Budget and Tax Limitation Amendment", in Proceedings of the Tax Foundation, $34^{\text {th }}$ National Conference, New York City, The Federal Fiscal Dilemma: Is there a Solution?, pp. 21-24.

Tobin, James [1983a], "Liquidity Preference, Separation and Asset Pricing", Zeitschrift für Betriebswirtschaft, 3, March, pp. 53-57.

Tobin, James [1983b], "Macroeconomics under Debate”, Mitsui Lecture, University of Birmingham, England, March, reprinted in Tobin [1996b], pp. 203-236.

Tobin, James [1984], “On the Efficiency of the Financial System”, Fred Hirsch Memorial Lecture, New York, Lloyds Bank Review, No. 153, July, pp. 1-15, reprinted in Tobin [1987], pp. 282-296.

Tobin, James [1986a], "On the Welfare Macroecomics of Government Financial Policy”, The Scandinavian Journal of Economics, 88(1), pp. 9-24. 
Tobin, James [1986b], “A Professional Autobiography”, in William Breit and Roger W. Spencer eds. Lives of the Laureates, pp. 113-134, Cambridge MA: The MIT Press.

Tobin, James [1987], Policies for Prosperity; Essays in a Keynesian Mode, Edited by Peter M. Jackson, Wheatsheaf Books, Brighton, Sussex.

Tobin, James [1988], “The Future of Social Security: One Economist's Assessment”, in Theodore R. Marmor and Jerry L. Mashaw, eds. Social Security: Beyond the Rhetoric of Crisis, Princeton N.J. : Princeton University Press, Ch. 2, pp. 41-68.

Tobin, James [1990a], "Social Security, Public Debt and Economic Growth", 1990 Frank M. Engl Lecture on Economic Security, in Tobin [1996a].

Tobin, James [1990b], "On the Theory of Macroeconomic Policy", De Economist 148(1), pp. 1-14.

Tobin, James [1991], "On living and trading with Japan: United States commercial and macroeconomic policies", Business Economics, January.

Tobin, James [1992a], "Money", in John Eatwell et. al. eds. The New Palgrave Dictionary of Money and Finance, Vol 2, pp. 770-779, London: Macmillan Press Ltd.

Tobin, James [1992b], "The invisible hand in modern macroeconomics", in Michael Fry (ed.), Adam Smith's Legacy, London, Routledge.

Tobin, James [1992c], “An Old Keynesian Counterattacks”, Eastern Economic Journal, 18(4), Fall.

Tobin, James [1993], "Price Flexibility and Output Stability: An Old Keynesian View", Journal of Economic Perspectives, 7(1), Winter, pp. 45-65.

Tobin, James [1995], "The Natural Rate as New Classical Macroeconomics", in Rod Cross ed. The Natural Rate Hypothesis Twenty-Five Years on, Cambridge, Cambridge University Press.

Tobin, James [1996a], Full Employment and Growth; Further Keynesian Essays on Policy, Edward Elgar, Cheltenham, UK.

Tobin, James [1996b], Essays in Economics; National and International, The MIT Press, Cambridge, Massachusetts.

Tobin, James [1997], "My 1950 Food Demand Study in Retrospect", Journal of Applied Econometrics, 12, pp. 647-650; reprinted in Magnus and Morgan [1999], Chapter 11, pp. 265-268.

Tobin, James and Jorge Braga de Macedo [1980], "The Short-Run Macroeconomics of Floating Exchange Rates: An Exposition", in John S. Chipman and Charles P. Kindleberger eds., Flexible Exchange Rates and the Balance of Payments: Essays in Memory of Egon Sohmen, pp. 5-28, Amsterdam, North Holland. 
Tobin, James and William C. Brainard [1963], "Financial Intermediaries and the Effectiveness of Monetary Controls", American Economic Review (Papers and Proceedings), 53, No. 2, May, pp. 383-400.

Tobin, James and William C. Brainard [1977], "Asset Markets and the Cost of Capital", in Economic Progress, Private Values and Public Policy: Essays in Honor of William Fellner, Richard Nelson and Bela Balassa eds. Amsterdam, North Holland, pp. 235-62.

Tobin, James and William C. Brainard [1990], "On Crotty's critique of q-theory", Journal of Post-Keynesian Economics, Summer, 12(4).

Tobin, James and William C. Brainard [1992], "On the Internationalisation of Portfolios", Oxford Economic Papers 44, pp. 553-565.

Tobin, James, William Brainard, John B. Shoven and Jeremy Bulow [1982], "Tax Reform and Income Redistribution: Issues and Alternatives", in James Tobin, Essays in Economics, Theory and Policy, pp. 585-609, the MIT Press, Cambridge

Massachusetts.

Tobin, James and Willem H. Buiter [1976], "Long-Run Effects of Fiscal and Monetary Policy on Aggregate Demand," Ch. IV in Monetarism: Studies in Monetary Economics, pp. 274-336. North-Holland.

Tobin, James and Willem Buiter [1980], " Fiscal and Monetary Policies, Capital Formation and Economic Activity", in George M. von Furstenberg ed. The Government and Capital Formation, pp. 73-151, Ballinger, Cambridge, Massachusetts.

Tobin, James and F. Trenery Dolbear Jr. [1963], "On the Relevance of Psychology to Economic Theory and Research", in Sigmund Koch ed. Psychology: A Study of Science, Vol. 6, New York: McGraw-Hill.

Tobin, James and Walter Dolde [1971], "Wealth, Liquidity, Consumption”, in Consumer Spending and Monetary Policy: The Linkages, Federal Reserve Bank of Boston, Conference Series No. 5.

Tobin, James and Michael Haliassos [1990], "The Macroeconomics of Government Finance", in Benjamin Friedman and Frank Hahn eds. Handbook of Monetary Economics, Vol. 2, pp. 889-959, Amsterdam: North Holland.

Tobin, James and D. Hester eds. [1967a], Risk Aversion and Portfolio Choice, Cowles Foundation Monograph No. 19, New York: J. Wiley \& Sons

Tobin, James and D. Hester eds. [1967b], Studies of Portfolio Behavior, Cowles Foundation Monograph No. 20, New York: J. Wiley \& Sons.

Tobin, James and D. Hester, eds.[1967c], Financial Markets and Economic Activity, Cowles Foundation Monograph No. 21, New York: J. Wiley \& Sons. 
Tobin, James, and H.S. Houthakker [1951], "The Effects of Rationing on Demand Elasticities", Review of Economic Studies, 18, pp. 1-14.

Tobin, James, Joseph A. Pechman and Peter M. Mieszkowski [1967], "Is a Negative Income Tax Practical”, Yale Law Journal, 77(1), November, pp. 1-27.

Tobin, James and Craig Swan [1969], "Money and Permanent Income: Some Empirical Tests", American Economic Review, 59, May, pp. 285-295.

Tobin, James and Murray Weidenbaum eds. [1988], Two Revolutions in Economic Policy; The First Economic Reports of Presidents Kennedy and Reagan, the MIT Press, Cambridge Mass.

Turnovsky, S. J. [1980], "The choice of monetary instruments under alternative forms of price expectations", Manchester School, March, pp. 39-62.

Tversky A. and D. Kahneman [1992],"Advances in prospect theory: Cumulative representation under uncertainty", Journal of Risk and Uncertainty 5, pp. 297-323.

Watts, Harold W. and James Tobin [1960], "Consumer expenditures and the capital account", in Irwin Friend and Robert Jones eds. Proceedings of the Conference on Consumption and Saving, vol. 2, University of Pennsylvania, pp. 1-48.

Weitzman, M.[1982], "Increasing Returns and the Foundation of Unemployment Theory", Economic Journal, 92, 787-804.

Williamson, Oliver E. [1987], The Economic Institutions of Capitalism, the Free Press, Simon and Schuster, New York, NY.

Woodford, M. (1995), 'Price-level Determinacy Without Control of a Monetary Aggregate', Carnegie-Rochester Conference Series on Public Policy 43, pp. 1-46.

Wouk, Herman [1951], The Caine Mutiny, Little Brown \& Co.

Yaari, M. E.[1965], "The uncertain lifetime, life insurance and the theory of the consumer", Review of Economic Studies, Vol. 32, April, pp. 137-50.

Yellen, Janet L. [1984], "Efficiency Wage Models of Unemployment", American Economic Review, Papers and Proceedings, 74, May, pp. 200-205. 